IZA DP No. 7543

Industrialization Lessons from BRICS:

A Comparative Analysis

Wim Naudé

Adam Szirmai

Alejandro Lavopa

August 2013

Forschungsinstitut zur Zukunft der Arbeit Institute for the Study of Labor 


\title{
Industrialization Lessons from BRICS: A Comparative Analysis
}

\author{
Wim Naudé \\ MsM, University of Maastricht, \\ UNU-MERIT and IZA \\ Adam Szirmai \\ UNU-MERIT, University of Maastricht \\ Alejandro Lavopa \\ UNU-MERIT, University of Maastricht
}

Discussion Paper No. 7543

August 2013

IZA

P.O. Box 7240

53072 Bonn

Germany

Phone: +49-228-3894-0

Fax: +49-228-3894-180

E-mail: iza@iza.org

Any opinions expressed here are those of the author(s) and not those of IZA. Research published in this series may include views on policy, but the institute itself takes no institutional policy positions. The IZA research network is committed to the IZA Guiding Principles of Research Integrity.

The Institute for the Study of Labor (IZA) in Bonn is a local and virtual international research center and a place of communication between science, politics and business. IZA is an independent nonprofit organization supported by Deutsche Post Foundation. The center is associated with the University of Bonn and offers a stimulating research environment through its international network, workshops and conferences, data service, project support, research visits and doctoral program. IZA engages in (i) original and internationally competitive research in all fields of labor economics, (ii) development of policy concepts, and (iii) dissemination of research results and concepts to the interested public.

IZA Discussion Papers often represent preliminary work and are circulated to encourage discussion. Citation of such a paper should account for its provisional character. A revised version may be available directly from the author. 
IZA Discussion Paper No. 7543

August 2013

\section{ABSTRACT}

\section{Industrialization Lessons from BRICS: A Comparative Analysis}

To date there has been few systematic and comparative empirical analyses of the nature of economic development in Brazil, Russia, India, China and South Africa (BRICS). We contribute to addressing this gap by exploring the patterns of structural change between 1980 and 2010, focusing on the manufacturing sector. We show that three of the BRICS are experiencing de-industrialization (Brazil, Russia and South Africa). China is the only country where an expanding manufacturing sector accounts for a significant part of aggregate growth. We explore the differences in patterns and causes of manufacturing between China and the other BRICS. These differences are down to differences in industrial policy: in China industrial policy supported both foreign and domestic investment for technological catch-up. It is the only country where FDI favoured the manufacturing sector and manufactured exports, and where domestic investment started becoming increasingly important compared to FDI from 1995 onward.

JEL Classification: F23, L52, L53, O25, O40, O33, O34

Keywords: foreign direct investment, multinational enterprises, industrialization, technology, innovation, entrepreneurship, Brazil, Russia, China, India, South Africa

Corresponding author:

Wim Naudé

Maastricht School of Management

P.O. Box 616

6200 MD Maastricht

The Netherlands

E-mail: naude@msm.nl 


\section{Introduction}

Scholars and policy makers alike remain fascinated by the development experiences of a group of emerging economies - Brazil, Russia, India, China and South Africa - often referred to as the BRICS (O'Neill, 2001). These economies have a sizeable impact on the global economy. In terms of combined GDP they are already larger than USA and the European Union. Whereas BRICS only accounted for less than 4 per cent of world exports during the early 1980s, by 2010 their combined share reached 13 per cent of world exports. They are regional economic leaders and they are attracting substantial amounts of foreign direct investment. This makes them interesting and important global decision-makers. But how much do their development experiences, particularly their success or failures in industrialization and manufacturing compare, and what can other countries, aspiring to industrial development learn from them?

Our concern with industrialization in general, and manufacturing specifically, is based on the recognition within the traditions of endogenous growth theory, evolutionary economics and institutional economics that manufacturing (industrialization) is important for economic development (Szirmai, 2012). Technological progress is in turn, necessary for successful industrialization (Von Tunzelmann, 1997; Fu, Pietrobelli and Soete, 2010). Hence in this paper we study and compare the industrialization experiences of the BRICS from the perspective of the links between structural change and technological upgrading.

We will focus on three specific issues: first the role manufacturing played in structural change and economic development in the BRICS; second how the experiences of the BRICS compare with regard to technological upgrading and catch up; and third, how oreign and domestic investment have contributed to structural change and catch up.

Our contribution is that to date there have been few systematic and comparative empirical analyses of the nature of industrialization in BRICS. An important first step in the analysis of structural change in four of the BRICS is provided in a recent paper by De Vries et al. (2012). Our paper complements theirs by providing a more detailed analysis of structural change within manufacturing, and moreover by detailing and discussing the respective roles of FDI and domestic investment over the period 1980 to 2010.

The paper is structured as follows. In section 2 we discuss the major issues in the literature on structural change, specifically relating to the role of technological upgrading through foreign and domestic sources. In section 3 we describe structural changes in BRICS between 1980 and 2010, emphasising manufacturing growth and changes within manufacturing. Then, in section 4 we analyse the extent of technology upgrading and the relative roles of MNEs and domestic investment. Section 5 concludes. 


\section{Literature Review: Structural Change and Technological Upgrading}

Industrialization - the rise of the manufacturing sector 1 - has been a sine qua non of structural economic change and development ever since the first Industrial Revolution (Szirmai, 2012a; O'Brien, 2001). It is associated with higher productivity growth and per capita incomes, described as a "structural bonus" (Timmer and Szirmai, 2000).

Among the central issues in the literature on industrialization are technological change 2 , and innovation, and the relative contributions of multinational enterprises (MNEs) and domestic investment in facilitating technological upgrading. Technology "gaps" characterises differences in per capita income and productivity between countries (Fagerberg, 2005, Kemeny, 2010, Szirmai, 2012b,c; Verspagen, 2005). Technology gaps provide a huge potential for catch up in the tradition of Gerschenkron (1982) and Abramovitz (1986), if absorptive capacities are in place - in the absence of which countries can fall behind.

The main channels through which emerging economies can access international knowledge and technology are through FDI and domestic investment. We will discuss these channels in the following sub-sections.

\subsection{FDI-Assisted Technological Catch-Up}

Technological progress and its diffusion were important for the First Industrial Revolution in Britain in the $18^{\text {th }}$ century. It was also vital for the (second revolution) industrialization of Continental Europe and the USA in the $19^{\text {th }}$ century, and for the (third revolution) industrialization of Japan and the East Asian NIEs in the $20^{\text {th }}$ century (O'Brien, 2001; Veloso and Soto, 2001). In each case catch up resulted from lagging countries accessing technology developed in leading nations, adapting it effectively to local circumstances, and subsequently relying more on indigenous innovation. Technology has become more important as ever, in the current modular and flexible production systems that has come to characterize the world economy. Indeed Marsh (2012) claims that the world is experiencing a new industrial revolution, lead by networked production, mass customization and new technologies, such as 3-D printing.

Multinational Enterprises (MNEs) can diffuse technologies to developing countries in three ways: (i) by directly transferring technology to affiliate or joint ventures (JV); (ii) through spillover effects, and/or (iii) through doing R\&D within a developing country (Lloyd, 1996).

\footnotetext{
1 Industrialization is defined as a socio-economic process that includes 'a rapid transformation in the significance of manufacturing activity in relation to all other forms of production and work undertaken within national (or local) economies' (O'Brien, 2001:7360).

2 Technologies are 'rules and ideas that direct the way goods and services are produced' (Kemeny, 2010:1544).
} 
The importance of such diffusion is well recognised. . For instance Fu, Pietrobelli and Soete (2010: 1206) states that "FDI has been 'a major vehicle for the transfer of advanced foreign technology to developing countries for a long time" (see also Veloso and Soto, 2001:88). More particularly FDI is "a vehicle through which developing country firms learn about new technology" (Harrison and Rodriguez-Clare, 2010: 4100). With MNEs as the "main engines of innovation in the world economy' (Franco et al., 2011:1249) such industrialization has been labelled "transnational-assisted restructuring" (Lloyd, 1996). Once sufficient absorptive capacities have developed, MNEs can bring technology and know-how to a local economy. This can take place either through foreign direct investment (FDI) and/or through non-equity modes (NEMs) of international production and/or through their global R\&D activities.

It should be stressed that the context within which technology became available was important. For instance in $18^{\text {th }}$ century Britain the country's access to cheap energy (coal), its location in terms of seaborne trade, and the substantial investments made by the state in the Royal Navy (lowering transport costs) as well as other measures to protect intellectual capital created a favourable context for industrialization (see O'Brien, 2001; Robinson, 2009; Von Tunzelmann, 1997). Similar considerations apply to China's recent industrial success, as section 4 below will make clear: relatively low-cost resources (labour in China vs. coal in Britain), trade (export-driven growth), a large domestic market and government policies and infrastructural investments. Importantly they played this role in conjunction with the adoption or acquisition of existing foreign technology 3 - with the latter first and foremost applied to make existing goods and later improve these through incremental innovations (Puga and Trefler, 2010). Indeed, China's industrialization has been described as foreign technology-led industrialization (Ozawa, 2011).

The point thus is that foreign technology-driven industrialization commences through innovations based on the adoption of foreign technologies that require lower-skilled human and entrepreneurial resources. As time passes a country can begin to add its own innovations, expanding the global technological frontier (Eberhardt et al., 2011). As such innovation, in a broad sense, is inherently part of the structural economic transformation process countries need to undergo (Fagerberg et al., 2010).

The much faster industrialization of China, as compared to that of Europe or the USA, reflects in part the "stage skipping" phenomenon, made possible by the country benefitting from the much more rapid diffusion of technologies by foreign firms and domestic efforts for acquisition of technology. The catch up country does not have to go through every stage of technological development. It can immediately jump from relatively backward levels of technology to

3 As Eberhardt et al. (2011:6) point out 'foreign firms conduct R\&D in China primarily to adopt existing products and patent existing innovations'. 
relatively advanced levels. In some technological fields, Chinese industrialization involved "leapfrogging", jumping directly from the imitation of mature technologies to innovation at the global frontier (Li and Lee, 2011).

In recent years it has been not only the technology transfer role of MNEs and FDI that has received attention as a mechanism for industrialization. The global fragmentation of production has also contributed to industrialization through the greater ease through which parts of a product's manufacturing may be outsourced and located in various countries (Nixson, 2012)4.

The emergence of global value chains has been driven by two broad 'unbundling' forces (Baldwin 2003). The "first unbundling" was due to better transport and freight handling and the liberalization of trade. These enabled geographically concentrated production. The second 'unbundling' resulted due to improvements in information and communication technologies (see Baldwin 2003).

Since the mid-1980s multinational enterprises (MNEs) used these better technologies and transport to break up their production processes across the globe; described as the spatial 'disintegration of production' (Feenstra, 1998). It allowed these MNEs to combine 'the high technology they developed at home with low-wage workers abroad' (Baldwin, 2011:7). Through this global value chains ${ }^{5}$ (GVCs) ('global production sharing') in production emerged (see for instance Houseman et al. 2010; Grossman and Helpman 2005; Kaplinksi 2011; Nordas 2008; Yi 2003; Hummels et al. 2001). International trade started to shift from 'trade in goods' to 'trade in tasks' (Bournakis et al. 2011). World trade in parts and components increased from US $\$ 502$ billion in 1992/1993 to US $\$ 1,1762$ billion by 2005/2006 (Athukorala and Menon 2010).

For industrially lagging countries the rise of global production sharing has radically changed the range of industrial policy instruments available- and has increased the importance of complementarities between foreign sources of technology and domestic absorption capabilities. This is because successful industrial development now requires countries to be competitive not in the complete production of some good, but in the production only of a component ('trade in tasks') wherein they need exceptional capabilities. Integrating a country's producers into global value chains may imply that the traditional focus of industrial policy on 'lumpy, complex industry' may not be appropriate anymore (Baldwin 2003; Kaplinksi 2011).

\footnotetext{
4 In the following paragraphs we rely on Naudé and Szirmai (2012). See also Szirmai et al (2013).

5 This is defined as 'the break-up of a production process into vertically separated stages carried out in two or more countries' (Athukorala and Menon, 2010:1).
} 
This development has opened up a range of opportunities for poorer countries, which may be more likely to be able to find a niche in which to specialize rather than be competitive along the entire production chain (Gimet et al. 2010). In other words finding a comparative advantage in a 'slice' of the production chain may perhaps be easier than finding a comparative advantage in the entire production chain and can be shaped by industrial policies (Coxhead and Jayasuriya, 2010). According to Baldwin (2011:2) global value chains have made industrialization for lagging countries much easier and quicker, stating that global value chains have "...opened a new industrialization path. Today, nations can industrialize by joining a supply chain...there is no need to build a supply chain...the concept of a one-nation supply chain has disappeared'. Global production sharing has also been shown, at least in theory, to result in static and dynamic efficiency gains (Bournakis et al. 2011; Rodriguez-Clare 2010 and Grossman and Rossi-Hansberg 2008).

But, as always, matters are not so simple. FDI and MNEs can perhaps better be seen as a twoedged sword in industrialization. The two-edged sword applies to both the technology transfer and global value chain integrating roles of FDI and MNEs.

As far as FDI as a vehicle for technology transfer is concerned, it is difficult to establish empirically whether and how important FDI is. It is econometrically difficult to identify the separate impact of FDI on host country economic performance, including productivity of firms (Harrison and Rodriguez-Clare, 2010:4100). Among others, this is due to high correlations between FDI inflows and trade openness, to endogeneity (and reverse causality) problems, and to 'omitted' variables associated with unobserved country heterogeneity.

Whether or not outward FDI by multinational enterprises is a source of technology transfer to developing countries is a question that has resulted in a an large empirical literature. Generally researchers' strategy have been to test whether the presence of a MNE in a developing country or region has increased the productivity of local firms or has had an impact on factor markets 6 (Harrison and Rodriguez-Clare, 2010).

There exist in principle two productivity influences - one is a direct productivity influence through for instance joint ventures (JVs), where the partner firm in a developing country directly benefits from the technological and managerial know-how of its foreign partner. A second influence is due to externalities whereby domestic firms' performance and productivity are affected - either positively or negatively - by the presence of the foreign firm or JV. The

\footnotetext{
6 In this paper our concern is with the technological spillovers, and hence we will not discuss the empirical literature on the impact of FDI on factor markets, except to refer the reader to the survey in Harrison and Rodriguez-Clare (2010), who conclude that MNEs do pay their workers higher wages and are more likely to comply with minimum wages and international labour standards.
} 
latter can occur through the competition from the MNE, through demonstration effects, through knowledge and technology flows and/or through supplier-buyer relations. Effects on competitors are referred to as horizontal spillovers and the effects on buyers and suppliers as vertical spillovers.

Empirical evidence has provided certainty on only one aspect as far as the productivity enhancing effects of FDI is concerned. This is that MNEs and foreign invested firms are significantly more productive than domestic firms (with productivity usually measured in terms of output per worker or total factor productivity - TFP) (Tuan et al., 2009). It is also the case that JVs and foreign firms are more innovative, as measured in terms of the R\&D and patent filings. For instance Eberhardt et al. (2011) using a firm-level panel dataset from China finds that foreign-invested firms have been responsible for most of the R\&D and patent applications since the late 1990s - and they quote Hu (2010) who found that between 1995 and 2004 patenting by MNEs in China increased on average by 30 per cent per year. Finally, MNEs are often (e.g. in China and Brazil) the companies that are primarily responsible for the growth of exports.

Although many of the studies on the productivity of joint ventures suffer from methodological shortcomings - such as endogeneity problems - a few studies that do control for this confirm that joint ventures are more productive due to their foreign shareholding (see e.g. Javorcik, 2004). This finding can be taken as support for industrial policies encouraging joint ventures. It is consistent with China's experiences in which the promotion of joint ventures was a high priority in the country's strategy to obtain foreign technology. Indeed as Harrison and Rodriguez-Clare (2010:4104) pointed out until recently 'wholly owned foreign firms are a rarity in China; most firms are joint ventures between locally (frequently state-owned) and foreign enterprises'. However, after 2000, the Chinese government relaxed the rules for foreign investment and allowed fully foreign-owned firms to operate on the Chinese market.

With respect to productivity spillovers the literature is mixed. Empirical studies have found horizontal spillovers in the same industry to be insignificant. This may not be surprising given that MNEs do not have any incentives for sharing their technological advantages with competitors in the domestic market (Harrison and Rodriguez-Clare, 2010). In fact, evidence for negative horizontal spillovers have been found, which may imply that MNE activity causes a reduction in the market share of domestic firms (Aitken and Harrison, 1999) or that MNEs lure highly skilled labour away from domestic firms in neighbouring regions (Wang et al. forthcoming). On the other hand, vertical spillovers may be empirically more significant particular backward spillovers that are generated when MNEs or joint ventures buy inputs from domestic producers. In such a case it is in their interest to ensure that these local suppliers supply high quality and reliable inputs. This evidence has been taken to support industrial 
policies that require foreign firms to source their inputs locally - so-called domestic content requirements - or that subsidize the use of domestic inputs by MNEs. These types of industrial policies have been used in emerging economies like Brazil, China, India and South Africa.

As far as integration into global value chains through MNEs is concerned, it may imply that although industrialization may be easier, it may also be less "meaningful" (Baldwin 2011). Thus we may not observe the same strong association between industrial exports and development as was the case earlier in the 20th century. Moreover, integration into global value chains and upgrading within the value chain will require a greater emphasis than before on innovation, transport and agglomeration effects, and less emphasis on "old" industrial policy instruments such as tariffs, exchange rate policy and quotas. This implies, as we already mentioned, that domestic investment in innovation capabilities becomes more, not less, important in the industrialization process (Szirmai et al., 2013).

We explore further in section four whether and how FDI has been harnessed to obtain technology in the BRICS and what role has it played in the past in successful (or unsuccessful) industrialization experiences in these countries. Before doing so, however, we need to discuss the second channel of accessing technology, namely investing domestic resources in innovation and national innovation systems and their support.

\subsection{Domestic Investment for Technology Adoption}

Whereas technological transfer through FDI may be important in theory, in practice it is often constrained due to a lack of domestic absorptive capacity. Hence domestic investment is also important. Some authors have raised the question of whether an exclusive reliance on FDI as driver of industrialization may not be ultimately self-defeating. Amsden (2011) for instance argues that the excessive reliance on foreign multinationals in Latin America explains its weaker performance compared with Asia where domestic firms have been more important. Through fragmentation of global production (outsourcing) these firms may hinder industrial catch-up and may even cause premature de-industrialization. Through transfer of technology and knowhow they may potentially speed up catch-up - but this is not automatic (Fagerberg et al., 2010). The lack of development of indigenous innovative capabilities may hence delay development. Empirical evidence seems to back this up. In a survey of the literature Harrison and RodriguezClare (2010) conclude that 'there is generally mixed evidence on the relationship between FDI and a country's growth' and that 'other complementary policies need to be in place to maximize the gains from inward foreign investment' (p.4100).

An enduring idea in thinking about MNEs and technological progress in developing countries is that the stage of development matters, and that FDI and domestic absorptive capacities will interact in different ways across different stages of development. Kemeny (2010) offers 
empirical evidence for this view. Using an unbalanced panel of 142 countries from 1975 to 2000 and using a GMM estimator to control for unobserved heterogeneity and endogeneity issues, he finds that FDI does indeed have a positive effect on technological upgrading, but that this effect depends on a country's level of development and absorptive capability. The conclusion is that poor countries can benefit substantially from FDI, but only if they have made complementary investments in absorptive capabilities. For more developed countries, which produce on the technological frontier, it is their absorptive capacities, rather than FDI that seem to play the most significant role in explaining economic growth and improvements in technological performance.

Countries often go beyond implementing complementary policies, given their understanding of the shortcomings of technology transfer through FDI. Some countries (such as e.g. Korea and Japan) have even considered MNEs as a threat to local production capacity and a cause for possible premature de-industrialization. Therefore, they have restricted the activities of MNEs either through trade barriers or through restrictions on sectors, firms and locations for FDI, often requiring a domestic partner as a condition for allowing MNEs to invest. At present, even countries with quite liberalized trade and investment regimes often place restrictions on foreign investments in service sectors such as finance, transport and communications, and restrict foreign ownership of land (UNCTAD, 2011). But given the increasingly indispensible role of MNCs in the production and diffusion of knowledge, the policy option of keeping MNCs at arm's length is harder to implement presently than it was in the past (Narula and Lall, 2006).

Whether and how countries benefit from their firms' integration in global value chains (GVCs) will depend on their indigenous innovation system as well as the type of global value chain that a firm finds itself in (Altenburg et al. 2008). According to Fu et al. (2010:1209) 'the risk of falling into a captive relationship, or even of being captured by a leader, diminishes with a stronger innovation system'. According to Altenburg et al. (2008) global value chains can make positive contributions when lead firms encourage innovation along the chain. For instance, Puga and Trefler (2010) document how assembly line firms have learned to "de-bug" production runs of MNEs, and in the process have gained experience in incremental innovations - the type of innovations that were a feature of all successful industrial revolutions in the past.

Global value chains can stimulate the development of personal networks (Altenburg et al., 2008; Saxenian, 2006). Personal networks have been important in China and India to facilitate the return of skilled professionals from the USA and elsewhere.

The interactions between foreign and domestic investment and foreign and domestic firms are thus of special interest for technological catch-up- but these interactions have generally been neglected in the literature. Moreover in the context of understanding the industrialization experiences of the BRICS, there is only a scant literature dealing with whether and how 
domestic investment, especially of the public sector, has facilitated or limited FDI and technology transfer.

The view that industrialization depends domestic capabilities (see e.g. Cimoli et al. 2006; Fagerberg et al., 2007) has led to a literature that advocates the development of 'national systems of production and innovation' (Nelson, 1993). Such systems aim to support the learning, development of absorptive capacities and an environment conducive to the commercialization of innovations (Cimoli, et al., 2006).

Within this literature the assumption of older neoclassical growth theory that technology would "costlessly and unconditionally"be adapted by developing countries is rejected. Rather, it is recognized that technology (and knowledge) is not a pure public good, but more accurately a quasi-public good (Kemeny, 2010). FDI can potentially bring many advantages including the diffusion of technology from lead to follower countries, but this depends on domestic investments - particularly but not exclusively in absorptive capacity and coordination, to overcome the market failures that characterize a quasi-public good such as technology (Franco et al., 2011). As Fu et al. (2010:1204) stress, technological diffusion and adoption depends on "substantial and well-directed technological efforts and on absorptive capacity". And according to O'Brien (2001:7362) "diffusion is now perceived as a complex process of creative adaptation rather than mere emulation. The transfer of technology only succeeds when a matrix of related capacities into which machinery can fit has been built up and is receptive to change".

Without well-developed indigenous capabilities, FDI may not be the agent of successful technology transfer (Franco et al., 2011). Its impacts on domestic firms may be insignificant, due to limited linkages and MNE restrictions on technology transfer, or even negative due to the crowding out of domestic firms (both from markets and from access to inputs such as skilled labour and finance). Under such conditions FDI could hinder local innovation, or could even lead to the adoption of inappropriate technologies (for instance labour-saving technologies in labour-surplus economies) in developing countries (Fu et al., 2010).

At firm level, absorptive capacity (also referred to as social capacity) has been defined as "the ability of an organisation to identify, assimilate, and exploit knowledge from its surrounding environment" (Fu et al., 2010:1210). It includes "trust and social capital, sound governmental and non-governmental institutions, human capital development, and managerial and technical competence" (Kemeny, 2010: 1545). The identification and exploitation of knowledge is taken to imply identification of profitable opportunities and commercialization of knowledge (Kemeny, 2010) - essentially characteristics of an entrepreneurial economy (Thurik, 2010). Absorptive capacity and FDI interact over the stages of development (Blonigen and Wang, 2005), with entrepreneurial capacities becoming more important at more advanced stages of development (Thurik, 2010; Ács and Naudé, 2013). 


\section{Patterns of Manufacturing Change in BRICS, $1980-2010$}

In the previous section we gave an overview of the literature on the sources of technology transfer. We argued that technological advance is central to industrialization and that it can be sourced from MNEs (FDI and GVCs) and from domestic firms and organizations. But, there are shortcomings with both mechanisms. The best outcomes in terms of industrialization may be achieved through a complementary approach. We are interested in whether this conclusion is borne out in the case of the BRICS.

\subsection{Structural Change and Manufacturing}

The composition of Value Added and Employment by major sectors in BRICS in $1980^{7}$ and 2008 is shown in Tables $1 \mathrm{a}$ and $1 \mathrm{~b}$ and the changes that can be observed between these years in Table 2 . All sources of data used henceforth are described in the Appendix.

Table 1a. Sectoral shares of Value Added (at constant prices). BRICS, 1980-2008 (in \%)

\begin{tabular}{|c|c|c|c|c|c|c|c|c|c|c|}
\hline & \multicolumn{2}{|c|}{ Brazil } & \multicolumn{2}{|c|}{ Russia } & \multicolumn{2}{|c|}{ India } & \multicolumn{2}{|c|}{ China } & \multicolumn{2}{|c|}{ South Africa } \\
\hline & 1980 & 2008 & 1995 & 2008 & 1980 & 2008 & 1987 & 2008 & 1980 & 2008 \\
\hline Agriculture & $4.9 \%$ & $6.4 \%$ & $7.2 \%$ & $4.2 \%$ & $37.4 \%$ & $16.3 \%$ & $29.9 \%$ & $9.2 \%$ & $3.5 \%$ & $2.6 \%$ \\
\hline Mining & $0.5 \%$ & $1.0 \%$ & $6.3 \%$ & $5.0 \%$ & $1.9 \%$ & $1.8 \%$ & $4.5 \%$ & $3.2 \%$ & $13.8 \%$ & $6.1 \%$ \\
\hline Manufacturing & $21.0 \%$ & $19.4 \%$ & $19.6 \%$ & $16.6 \%$ & $14.9 \%$ & $16.4 \%$ & $22.2 \%$ & $44.7 \%$ & $21.9 \%$ & $18.4 \%$ \\
\hline Utilities & $1.4 \%$ & $2.5 \%$ & $4.2 \%$ & $2.5 \%$ & $1.8 \%$ & $2.2 \%$ & $2.6 \%$ & $2.7 \%$ & $1.8 \%$ & $2.1 \%$ \\
\hline Construction & $7.6 \%$ & $4.8 \%$ & $6.6 \%$ & $7.2 \%$ & $5.8 \%$ & $6.3 \%$ & $6.4 \%$ & $5.0 \%$ & $4.1 \%$ & $3.3 \%$ \\
\hline Services & $64.5 \%$ & $65.9 \%$ & $56.1 \%$ & $64.5 \%$ & $38.2 \%$ & $57.1 \%$ & $34.3 \%$ & $35.1 \%$ & $60.8 \%$ & $67.5 \%$ \\
\hline Total & $100.0 \%$ & $100.0 \%$ & $100.0 \%$ & $100.0 \%$ & $100.0 \%$ & $100.0 \%$ & $100.0 \%$ & $100.0 \%$ & $100.0 \%$ & $100.0 \%$ \\
\hline
\end{tabular}

Source: Authors' estimations based on de Vries et al (2012), Statistics South Africa and UNIDO INDSTAT 2011

7 In the cases of China and Russia comparable data is only available since 1987 and 1995 respectively. In what follows, our starting point for the two economies will be given by those years. 
Table 1b. Sectoral shares of Employment. BRICS, 1980-2008 (in \%)

\begin{tabular}{lcccccccccc}
\hline & \multicolumn{2}{c}{ Brazil } & \multicolumn{2}{c}{ Russia } & \multicolumn{2}{c}{ India } & \multicolumn{2}{c}{ China } & \multicolumn{3}{c}{ South Africa } \\
& $\mathbf{1 9 8 0}$ & $\mathbf{2 0 0 8}$ & $\mathbf{1 9 9 5}$ & $\mathbf{2 0 0 8}$ & $\mathbf{1 9 8 0}$ & $\mathbf{2 0 0 8}$ & $\mathbf{1 9 8 7}$ & $\mathbf{2 0 0 8}$ & $\mathbf{1 9 8 0}$ & $\mathbf{2 0 0 8}$ \\
\hline Agriculture & $38.4 \%$ & $17.8 \%$ & $27.7 \%$ & $21.5 \%$ & $69.9 \%$ & $54.0 \%$ & $59.2 \%$ & $40.2 \%$ & $12.6 \%$ & $5.7 \%$ \\
Mining & $0.5 \%$ & $0.3 \%$ & $1.4 \%$ & $1.2 \%$ & $0.5 \%$ & $0.6 \%$ & $1.8 \%$ & $1.3 \%$ & $11.1 \%$ & $2.4 \%$ \\
Manufacturing & $12.8 \%$ & $13.0 \%$ & $17.3 \%$ & $13.7 \%$ & $10.3 \%$ & $12.3 \%$ & $16.0 \%$ & $18.5 \%$ & $15.0 \%$ & $14.3 \%$ \\
Utilities & $0.8 \%$ & $0.4 \%$ & $1.9 \%$ & $2.3 \%$ & $0.3 \%$ & $0.3 \%$ & $0.3 \%$ & $0.5 \%$ & $1.6 \%$ & $0.7 \%$ \\
Construction & $8.9 \%$ & $7.2 \%$ & $7.7 \%$ & $7.3 \%$ & $1.9 \%$ & $6.7 \%$ & $4.5 \%$ & $6.7 \%$ & $7.8 \%$ & $8.3 \%$ \\
Services & $38.6 \%$ & $61.3 \%$ & $44.0 \%$ & $54.0 \%$ & $17.1 \%$ & $26.0 \%$ & $18.3 \%$ & $32.8 \%$ & $51.8 \%$ & $68.6 \%$ \\
\hline Total & $\mathbf{1 0 0 . 0 \%}$ & $\mathbf{1 0 0 . 0 \%}$ & $\mathbf{1 0 0 . 0 \%}$ & $\mathbf{1 0 0 . 0 \%}$ & $\mathbf{1 0 0 . 0 \%}$ & $\mathbf{1 0 0 . 0 \%}$ & $\mathbf{1 0 0 . 0 \%}$ & $\mathbf{1 0 0 . 0 \%}$ & $\mathbf{1 0 0 . 0 \%}$ & $\mathbf{1 0 0 . 0 \%}$ \\
\hline
\end{tabular}

Source: Authors' estimations based on de Vries et al (2012), Statistics South Africa and UNIDO INDSTAT 2011

Tables $1 \mathrm{a}$ and $1 \mathrm{~b}$ show that China is the only country where the share of manufacturing increased dramatically. By 2008, manufacturing was the sector with the largest share in GDP. 8 In India, there has been a modest increase in the share of manufacturing, but services have become by far the largest sector of the economy. In Brazil, Russia and South Africa the shares of manufacturing declined somewhat, pointing to de-industrialization, while the shares of services increased. In these three countries the share of services in GDP stood at around 65 per cent in 2008. In South Africa and, to a lesser extent in Russia the relatively large contribution of mining to GDP at the beginning of the period stands out. While in South Africa it accounted for almost $14 \%$ of GDP, in Russia this was $6 \% 9$. By 2008 , the shares of mining had declined, in the case of South Africa very substantially. China and India have experienced most structural change, as indicated by the average of absolute percentage changes, with large declines in the shares of agriculture and large increases in respectively manufacturing and services.

8 The 2008 manufacturing share of 44 per cent in constant 1995 prices derived from de Vries et al. 2012 is substantially higher than in other published estimates, possibly deriving from confusion concerning data about industry versus manufacturing. But all estimates indicate that the shares of manufacturing in China are extremely high. Thus the share of industry at current prices, including mining and utilities in 2008, published in the China Statistical Yearbook of 2010 is 40.5 per cent. The share in constant 1990 prices for 2000 is over fifty per cent.

9 Given the importance of gas and oil in this country, it would be expected an even larger share in GDP. According to de Vries et al (2012), this fact could be explained due to transfer pricing in which large oil companies use trading companies to bring their output to market. Consequently, part of the value added of mining is computed in wholesale trade. 
Table 2. Changes in sectoral shares of Value Added (VA) and Employment (N). BRICS, 1980-2008

(in percentage points)

\begin{tabular}{|c|c|c|c|c|c|c|c|c|c|c|}
\hline & \multicolumn{2}{|c|}{$\begin{array}{c}\text { Brazil } \\
(1980-2008)\end{array}$} & \multicolumn{2}{|c|}{$\begin{array}{c}\text { Russia } \\
\text { (1995-2008) }\end{array}$} & \multicolumn{2}{|c|}{$\begin{array}{c}\text { India } \\
(1980-2008)\end{array}$} & \multicolumn{2}{|c|}{$\begin{array}{c}\text { China } \\
(1987-2008)\end{array}$} & \multicolumn{2}{|c|}{$\begin{array}{l}\text { South Africa } \\
\text { (1980-2008) }\end{array}$} \\
\hline & VA & $\mathbf{N}$ & VA & $\mathbf{N}$ & VA & $\mathbf{N}$ & VA & $\mathbf{N}$ & VA & $\mathbf{N}$ \\
\hline Agriculture & 1.54 & -20.63 & -2.99 & -6.18 & -21.13 & -15.89 & -20.70 & -18.96 & -0.90 & -6.99 \\
\hline Mining & 0.46 & -0.20 & -1.31 & -0.18 & -0.11 & 0.15 & -1.31 & -0.51 & -7.66 & -8.72 \\
\hline Manufacturing & -1.66 & 0.24 & -2.94 & -3.58 & 1.51 & 2.08 & 22.45 & 2.52 & -3.55 & -0.67 \\
\hline Utilities & 1.10 & -0.34 & -1.63 & 0.36 & 0.37 & 0.04 & 0.11 & 0.22 & 0.27 & -0.96 \\
\hline Construction & -2.76 & -1.76 & 0.56 & -0.40 & 0.45 & 4.81 & -1.39 & 2.23 & -0.84 & 0.55 \\
\hline Services & 1.32 & 22.69 & 8.31 & 9.98 & 18.90 & 8.82 & 0.84 & 14.50 & 6.72 & 16.79 \\
\hline
\end{tabular}

Source: Authors' estimations using same sources than Table 1

Thus, China and India's GDP per capita growth10 has been accompanied by structural changes away from agriculture, and into manufacturing and services, respectively. In Russia, rapid growth since 1997 has not seen a growing manufacturing share - on the contrary, the manufacturing sector's share of value added shrank the most in Russia - by almost 3 percentage points between 1995 and 2008. This de-industrialization11 is often typical of gas/oil-rich countries. The other resource-rich BRICS economy - South Africa - has likewise experienced a shrinking manufacturing share - but strangely an even larger decline in the relative share of mining, over a period that includes one of the strongest commodity booms since the Second World War. As in Russia, the service sector has become the dominant sector in South Africa, and is also dominant in Brazil. In fact, the services sector was already by far the largest sector in Brazil in 1980.

Summarizing the above trends, it is clear that the rapid economic growth has typically occurred in the two BRICS where most structural change has taken place and where manufacturing continues to play a substantial role such as China, and to a much lesser extent India. The different patterns of structural change illustrate the extreme heterogeneity of the BRICS.

10 A comment about the economic growth rates of BRICS is in order. Over the period 1990 to 2008 the average annual GDP per capita growth rates in BRICS were respectively $1.6 \%, 0.8 \%, 4.6 \%, 8.4 \%$ and $1.5 \%$. Thus apart from China and perhaps India, growth rates in these economies have been quite modest.

11 A shrinking share of manufacturing in value added is not per se an indication of premature de-industrialization. This depends on the level of per capita income at which de-industrialisation takes place, as well as the productivity dynamics within the manufacturing sector. If the share of manufacturing starts declining too early and the sector is stagnant, than de-industrialisation is problematic. 


\subsection{Structural change within manufacturing}

To better understand the role of the manufacturing sector it is also necessary to consider the changing composition of a country's manufacturing sector. Within this sector a number of prominent changes have taken place. Tables 5 to 6 summarize the percentage changes in the main manufacturing sub-sectors over the period under investigation in the BRICS countries.

Table 5a. Sectoral shares of Manufacturing Value Added (at constant LCU). BRICS, 1980-2008 (in \%)

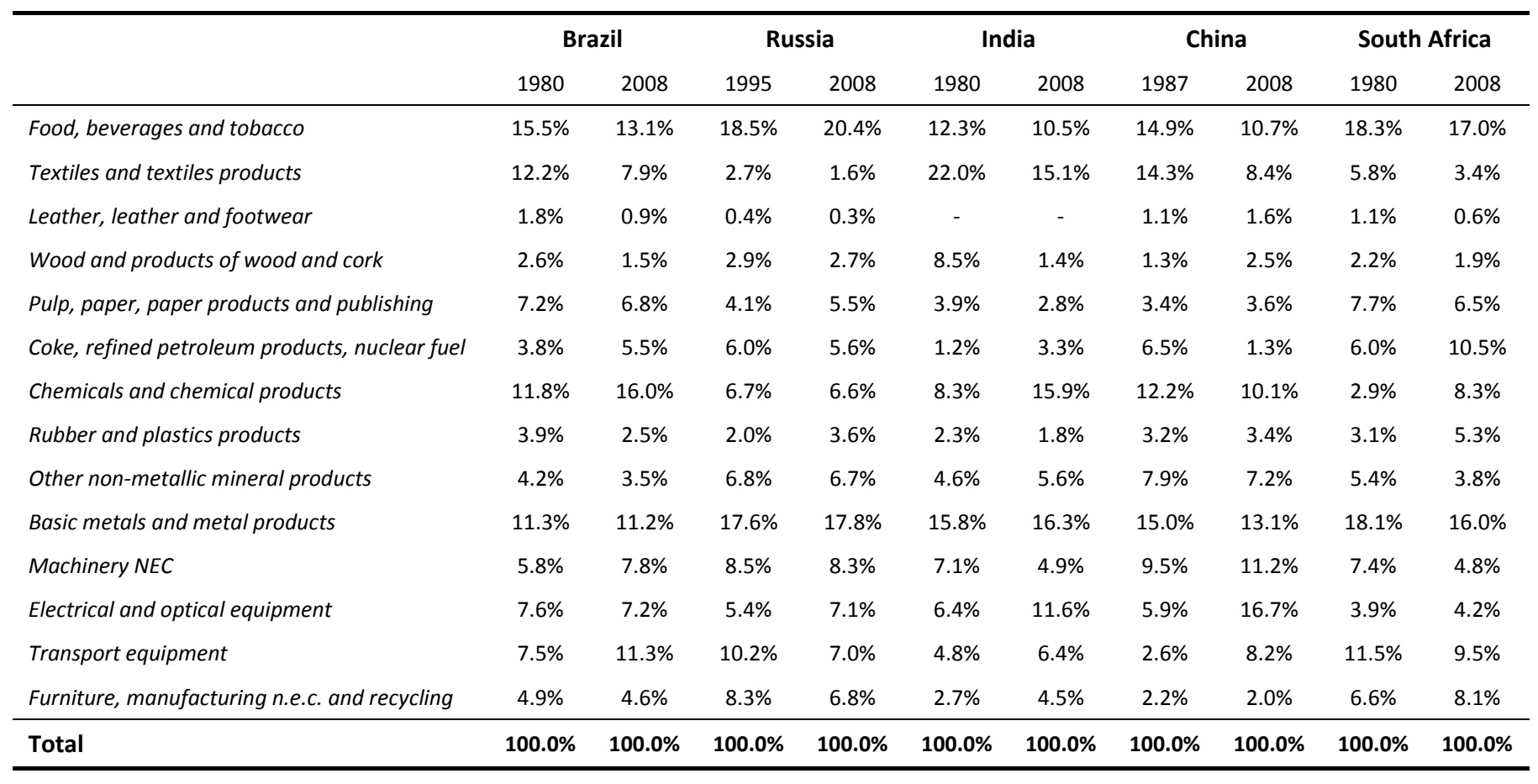

Source: Authors' estimations based on de Vries et al (2012), Statistics South Africa and UNIDO INDSTAT 2011 
Table 5b. Sectoral shares in Manufacturing Employment. BRICS, 1980-2008 (in \%)

\begin{tabular}{|c|c|c|c|c|c|c|c|c|c|c|}
\hline & \multicolumn{2}{|c|}{ Brazil } & \multicolumn{2}{|c|}{ Russia } & \multicolumn{2}{|c|}{ India } & \multicolumn{2}{|c|}{ China } & \multicolumn{2}{|c|}{ South Africa } \\
\hline & 1980 & 2008 & 1995 & 2008 & 1980 & 2008 & 1987 & 2008 & 1980 & 2008 \\
\hline Food, beverages and tobacco & $17.3 \%$ & $18.9 \%$ & $12.5 \%$ & $16.4 \%$ & $20.1 \%$ & $17.0 \%$ & $10.6 \%$ & $10.2 \%$ & $15.0 \%$ & $15.7 \%$ \\
\hline Textiles and textiles products & $26.3 \%$ & $23.5 \%$ & $9.3 \%$ & $5.8 \%$ & $34.6 \%$ & $32.6 \%$ & $15.0 \%$ & $15.1 \%$ & $15.4 \%$ & $9.0 \%$ \\
\hline Leather, leather and footwear & $4.9 \%$ & $5.1 \%$ & $1.5 \%$ & $0.9 \%$ & - & - & $2.2 \%$ & $4.6 \%$ & $2.5 \%$ & $1.4 \%$ \\
\hline Wood and products of wood and cork & $4.7 \%$ & $3.8 \%$ & $4.1 \%$ & $5.2 \%$ & $13.4 \%$ & $9.7 \%$ & $3.4 \%$ & $6.9 \%$ & $5.7 \%$ & $4.2 \%$ \\
\hline Pulp, paper, paper products and publishing & $5.9 \%$ & $4.9 \%$ & $2.7 \%$ & $4.0 \%$ & $2.3 \%$ & $3.2 \%$ & $4.9 \%$ & $8.0 \%$ & $5.1 \%$ & $6.6 \%$ \\
\hline Coke, refined petroleum products, nuclear fuel & $0.8 \%$ & $1.3 \%$ & $1.9 \%$ & $2.0 \%$ & $0.1 \%$ & $0.1 \%$ & $0.5 \%$ & $0.7 \%$ & $1.2 \%$ & $1.2 \%$ \\
\hline Chemicals and chemical products & $5.0 \%$ & $4.0 \%$ & $5.1 \%$ & $4.8 \%$ & $3.0 \%$ & $3.7 \%$ & $5.6 \%$ & $5.5 \%$ & $5.4 \%$ & $5.4 \%$ \\
\hline Rubber and plastics products & $2.9 \%$ & $3.4 \%$ & $1.8 \%$ & $2.9 \%$ & $0.6 \%$ & $1.2 \%$ & $5.1 \%$ & $8.2 \%$ & $3.0 \%$ & $4.0 \%$ \\
\hline Other non-metallic mineral products & $5.1 \%$ & $5.0 \%$ & $7.4 \%$ & $6.9 \%$ & $8.6 \%$ & $8.8 \%$ & $13.6 \%$ & $5.8 \%$ & $5.6 \%$ & $5.2 \%$ \\
\hline Basic metals and metal products & $7.9 \%$ & $8.6 \%$ & $9.7 \%$ & $11.0 \%$ & $6.7 \%$ & $6.9 \%$ & $8.3 \%$ & $6.8 \%$ & $18.0 \%$ & $15.3 \%$ \\
\hline Machinery NEC & $4.0 \%$ & $5.0 \%$ & $19.8 \%$ & $15.4 \%$ & $2.0 \%$ & $2.6 \%$ & $11.7 \%$ & $8.1 \%$ & $5.9 \%$ & $7.9 \%$ \\
\hline Electrical and optical equipment & $3.7 \%$ & $4.3 \%$ & $9.8 \%$ & $8.7 \%$ & $1.3 \%$ & $2.0 \%$ & $5.6 \%$ & $10.7 \%$ & $5.3 \%$ & $5.3 \%$ \\
\hline Transport equipment & $3.5 \%$ & $4.7 \%$ & $11.2 \%$ & $11.1 \%$ & $1.4 \%$ & $2.5 \%$ & $3.3 \%$ & $4.2 \%$ & $7.1 \%$ & $10.9 \%$ \\
\hline Furniture, manufacturing n.e.c. and recycling & $8.0 \%$ & $7.5 \%$ & $3.3 \%$ & $4.9 \%$ & $5.7 \%$ & $9.6 \%$ & $10.2 \%$ & $5.4 \%$ & $4.7 \%$ & $8.0 \%$ \\
\hline Total & $100.0 \%$ & $100.0 \%$ & $100.0 \%$ & $100.0 \%$ & $100.0 \%$ & $100.0 \%$ & $100.0 \%$ & $100.0 \%$ & $100.0 \%$ & $100.0 \%$ \\
\hline
\end{tabular}

Source: Authors' estimations based on de Vries et al (2012), Statistics South Africa and UNIDO INDSTAT 2011

Table 6. Changes in sectoral shares in Manufacturing Value Added and Employment.

BRICS, 1980-2008 (in \%)

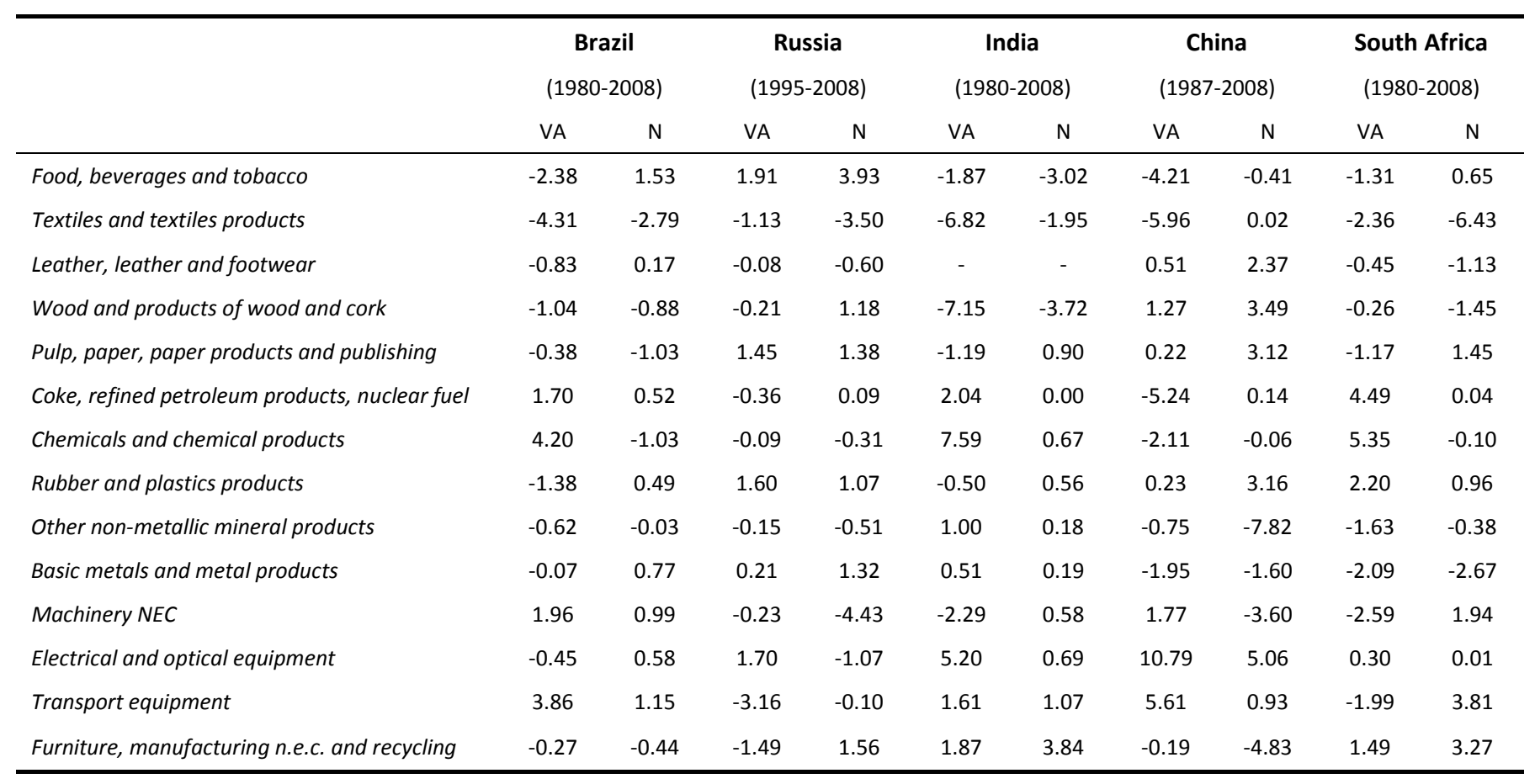

Source: Authors' estimations using same sources than Table 1 
These tables suggest that there has been a gradual shift from more labour intensive manufacturing to more capital-intensive (and higher skill-intensive) manufacturing in BRICS countries. Thus sectors such as food processing, textiles, leather and footwear and wood and wood products (typically labour- and low-skill intensive sectors) tend to decline in importance. Value added shares have been increasing in more capital intensive sectors such as chemicals, machinery, electrical and optimal equipment and transport equipment.

Some country-specific features that stand out are the increase in value added share in the petroleum and chemicals sub-sectors in Brazil, India and South Africa, the transport equipment sector in China and Brazil, rubber and plastics in Russia. Importantly the share of high-tech activities in electrical and optical equipment in China and India has been increasing.

The types of manufactured goods and services exported provide an interesting further glimpse into the different patterns of structural change in BRICS that has so far been identified. In the case of services exports - significant in Brazil, India and South Africa - the main sub-sectors have been renting of machinery and equipment and other business activities in Brazil, IT services in India, and transport services in South Africa.

A breakdown of shares in manufactured exports is shown in Table 8 . Looking at Table 8 we see that the most radical changes in the structure of manufactured exports have taken place in China and India. These countries managed to transform their specialization pattern within manufacturing exports, shifting from an export structure concentrated in labour intensive and low-tech products (mainly Food and Textiles) towards a structure concentrated in capital intensive and high-tech products (Metal products, Machinery and Electrical equipment in China and Chemicals and Other manufacturing goods in India). Less radical changes, but in the same direction, can be observed in Brazil and South Africa, where Transport equipment, machinery and electrical equipment have gained shares. In contrast, Russian manufacturing exports show a trend towards a specialization in refined petroleum products (driven by its oil and gas resources). 
Table 8. Change in sectoral composition of manufacturing exports from BRICS. 1980-2009 (Share over manufacturing exports) Percentage

\begin{tabular}{|c|c|c|c|c|c|c|c|c|c|c|c|c|c|c|c|}
\hline & \multicolumn{3}{|c|}{ Brazil } & \multicolumn{3}{|c|}{ Russia } & \multicolumn{3}{|c|}{ India } & \multicolumn{3}{|c|}{ China } & \multicolumn{3}{|c|}{ South Africa } \\
\hline & 1983 & 2009 & ch. & 1996 & 2009 & ch. & 1980 & 2009 & ch. & 1985 & 2009 & ch. & $\begin{array}{c}198 \\
0\end{array}$ & 2009 & ch. \\
\hline Food, beverages and tobacco & 32.8 & 30.5 & -2.4 & 2.7 & 3.3 & 0.6 & 9.6 & 5.2 & -4.4 & 15.7 & 1.9 & -13.7 & 18.8 & 7.1 & -11.6 \\
\hline Textiles and textiles products & 4.6 & 0.9 & -3.6 & 1.2 & 0.2 & -1.0 & 26.6 & 5.5 & -21.0 & 22.4 & 4.9 & -17.5 & 1.5 & 0.8 & -0.7 \\
\hline $\begin{array}{l}\text { Leather, leather and } \\
\text { footwear }\end{array}$ & 6.4 & 2.5 & -3.9 & 0.7 & 0.2 & -0.5 & 12.1 & 8.0 & -4.1 & 4.8 & 10.4 & 5.6 & 0.9 & 0.4 & -0.5 \\
\hline $\begin{array}{l}\text { Wood and products of wood } \\
\text { and cork }\end{array}$ & 1.6 & 1.6 & 0.0 & 2.2 & 3.0 & 0.8 & 0.8 & 0.1 & -0.7 & 0.0 & 0.7 & 0.7 & 0.4 & 0.3 & -0.2 \\
\hline $\begin{array}{l}\text { Pulp, paper, paper products } \\
\text { and publishing }\end{array}$ & 3.3 & 5.0 & 1.7 & 4.1 & 2.3 & -1.8 & 0.2 & 0.5 & 0.3 & 0.0 & 0.9 & 0.9 & 3.9 & 3.1 & -0.7 \\
\hline $\begin{array}{l}\text { Coke, refined petroleum } \\
\text { products, nuclear fuel }\end{array}$ & 7.2 & 3.2 & -4.0 & 18.7 & 40.7 & 22.0 & 2.1 & 16.2 & 14.2 & 41.0 & 1.3 & -39.6 & 0.6 & 3.7 & 3.1 \\
\hline $\begin{array}{l}\text { Chemicals and chemical } \\
\text { products }\end{array}$ & 8.2 & 11.5 & 3.3 & 14.1 & 11.6 & -2.5 & 10.6 & 12.6 & 2.0 & 5.4 & 5.6 & 0.2 & 14.5 & 10.2 & -4.3 \\
\hline Rubber and plastics products & 0.9 & 2.3 & 1.4 & 1.0 & 0.8 & -0.2 & 2.2 & 1.2 & -1.0 & 0.8 & 3.4 & 2.6 & 0.6 & 1.2 & 0.6 \\
\hline $\begin{array}{l}\text { Other non-metallic mineral } \\
\text { products }\end{array}$ & 0.7 & 1.4 & 0.7 & 0.8 & 0.8 & 0.0 & 1.2 & 1.2 & -0.1 & 0.2 & 2.0 & 1.8 & 1.5 & 0.8 & -0.7 \\
\hline $\begin{array}{l}\text { Basic metals and metal } \\
\text { products }\end{array}$ & 13.9 & 13.1 & -0.8 & 39.0 & 26.6 & -12.4 & 7.6 & 9.9 & 2.3 & 3.5 & 8.6 & 5.1 & 40.6 & 39.1 & -1.5 \\
\hline Machinery NEC & 5.9 & 7.9 & 2.0 & 3.9 & 3.0 & -0.8 & 6.1 & 4.8 & -1.3 & 0.9 & 22.0 & 21.1 & 4.0 & 9.6 & 5.7 \\
\hline $\begin{array}{l}\text { Electrical and optical } \\
\text { equipment }\end{array}$ & 3.1 & 5.6 & 2.4 & 3.4 & 2.9 & -0.4 & 3.5 & 6.6 & 3.1 & 1.5 & 26.5 & 25.0 & 1.6 & 3.9 & 2.4 \\
\hline Transport equipment & 10.8 & 13.3 & 2.6 & 7.8 & 3.2 & -4.7 & 14.4 & 6.5 & -7.9 & 0.8 & 5.7 & 4.9 & 2.9 & 14.4 & 11.5 \\
\hline $\begin{array}{l}\text { Furniture, manufacturing } \\
\text { n.e.c. and recycling }\end{array}$ & 0.5 & 1.1 & 0.7 & 0.4 & 1.3 & 0.9 & 3.1 & 21.6 & 18.5 & 3.2 & 6.0 & 2.8 & 8.3 & 5.0 & -3.0 \\
\hline Total & 100 & 100 & - & 100 & 100 & - & 100 & 100 & - & 100 & 100 & - & 100 & 100 & - \\
\hline
\end{tabular}

Source: Authors' estimations based on UN-COMTRADE

\section{Technological Upgrading and Industrialization}

In the previous section we noted that most rapid economic growth has occurred in BRICS where most structural change has taken place and where manufacturing continues to play a substantial role in production and exports such as China, and to a lesser extent India. We also noted that structural change has taken place within manufacturing, away from labour intensive manufacturing towards more capital (and technological/skill) intensive production. This is likely to create further impetus for technological upgrading, with the notable exception of Russia.

\subsection{Domestic Absorption Capability}

In section 2 we detailed the importance of both MNEs and domestic absorption capabilities for achieving domestic technological upgrading. In the remainder of this statistical overview, we investigate the extent to which structural change has been driven by MNEs/FDI or by domestic investments in absorptive capabilities. We start with the latter, investigating the extent of investment and achievements in science and technology in the BRICS. 
We measure scientific and technological investment in BRICS using three commonly used indicators: (i) R\&D as percentage of GDP; (ii) Patents granted by the US Patent Office and (iii) Scientific papers per head of population. These measures include input as well as output measures of science and technological capability. Figure 8 presents the extent of R\&D in BRICS. We compare the investments made by BRICS to those in the USA using smoothed five-year averages.

Figure 8. R\&D expenditures as \% of GDP (5 year averages). BRICS countries, MiddleIncome countries and US. 1981-2008

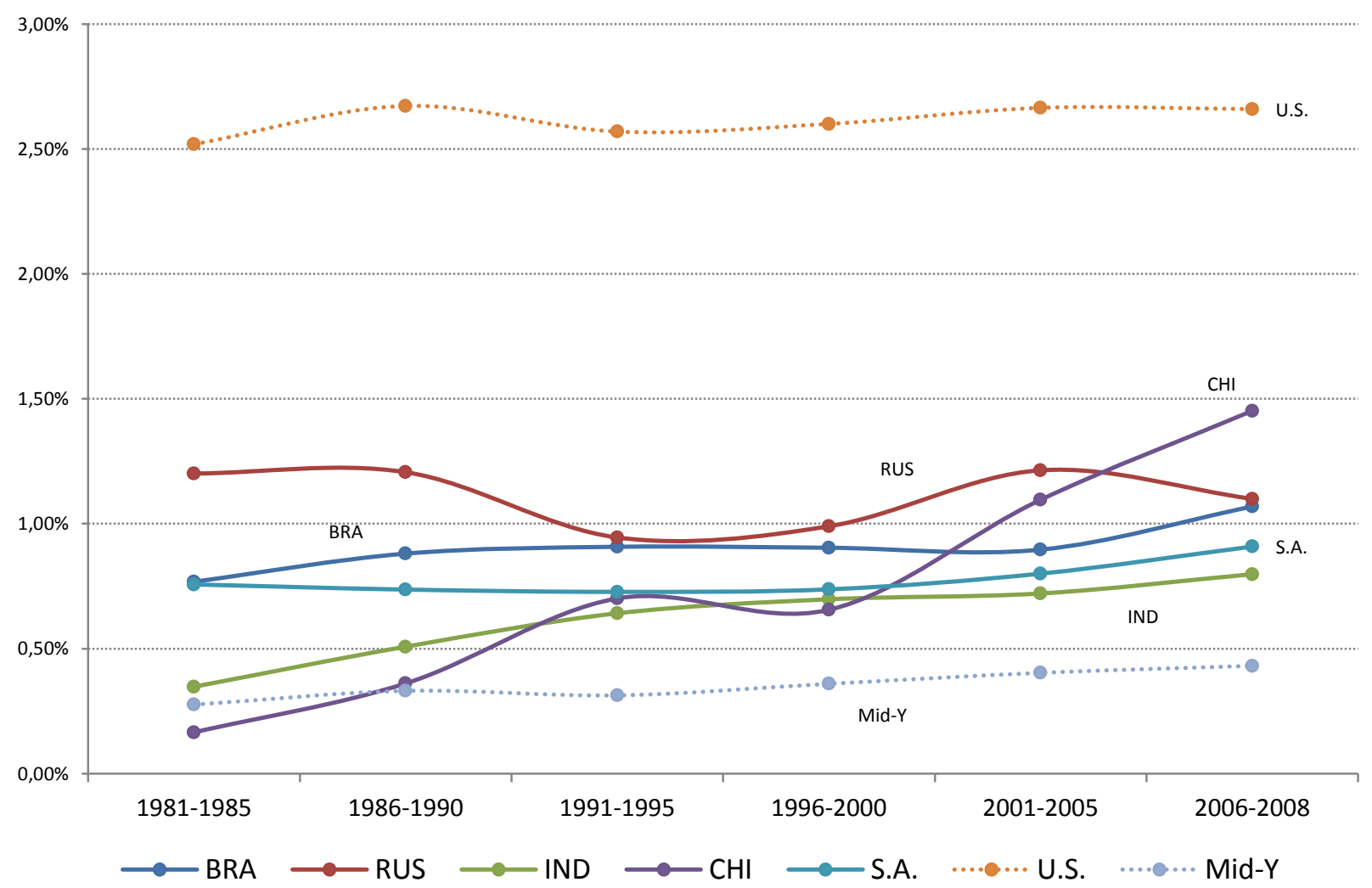

Source: Authors' estimations based on Castellacci and Natera (2011)

Figure 8 shows that over the period 1981-2008 R\&D expenditures were far above the average for middle income countries (Mid-Y) in all of the BRICS (except China before 1986).12. The most significant growth in R\&D has been in China (especially since 1996) and in India (although the level of R\&D in the latter country is still the lowest of all the BRICS). It is noticeable that in the case of Russia R\&D expenditure in 2008 is lower than in 1981 (with a strong decline since 2001

12 The group of middle income countries has been defined following World Bank's WDI classification. Note however that this group covers a diverse range of income levels starting from countries close to a low income level, such as India, and those nearly graduating into the high income group. Therefore, an alternative way to better benchmark BRICS performances could have been to use upper middle income and lower middle income levels instead. 
in Russia). In South Africa and Brazil there are very modest increases in the R\&D percentages since 1981. The figure also illustrates how large the gap is between the best BRICS performer, China and the USA. Finally, India and China were at about the same level of R\&D expenditures as late as 1996-2000, but thereafter China left India far behind and become the best performer among the BRICS.

The second indicator of achievement in science and technology is the number of patents granted by the US Patent and Trademark Office (USPTO). It is an output indicator of achievement. For the BRICS the trends since 1979 are depicted in Figure 9. From this figure the remarkable achievements of China and India are evident. In China, unlike in the other countries, the growth in the number of patents registered shows no sign of slowing down. In India, growth in new patent registrations has been rapid between 1994 and 2000, but has thereafter tapered off, as was the case with R\&D expenditures. The other counties - most notably Russia, Brazil and South Africa have seen a decline in patents since 2000. South Africa is perhaps the worst performer - by the early 1980 s the country was second only to Russia with regard to patent registrations, but by 2008 it was producing the least number of new patents.

Figure 9. Number of Patents granted in the USPTO (5 year sum). BRICS countries, 1979-2008.

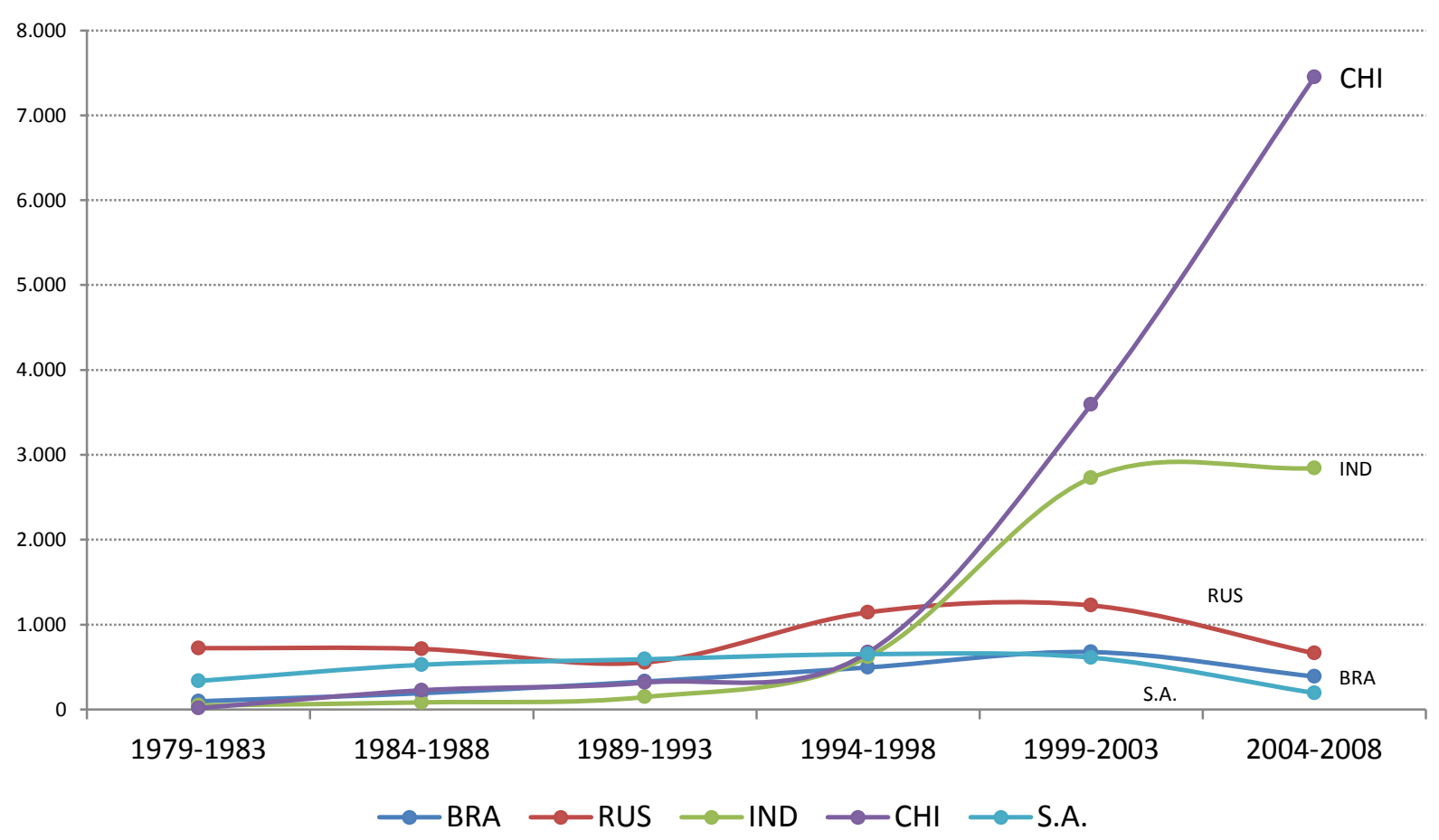

Source: Authors' estimations based on OECD Stats online

A third indicator of achievement in science and technology is the number of scientific papers published per head of population. Figure 11 depicts the situation in this regard for BRICS. With 
the exception of South Africa, it reflects a positive trend. Russia stands out as by far the most productive country in this respect. China and India contribute very large numbers of papers in absolute terms, but given their large populations, the per capita results are low. Brazil has made considerable progress. In 1981-5, it started out with similar levels of scientific publications as India and China, achieved sustained growth surpassing that of middle-income countries and reached levels similar to those of South Africa. The latter country, consistent with the trends in figures 8 and 9, has experienced a sharp decline in scientific publishing since the early 1990s. In contrast, patents have been declining in Brazil, Russia and South Africa, although they remain the countries with the highest per capita numbers of scientific articles. The latter reflect higher levels of educated workers (particularly scholars) in these countries.

Figure 10. Number of scientific and engineering articles per million of inhabitants (5 year averages in BRICS and average middle-income country, 1981-2008

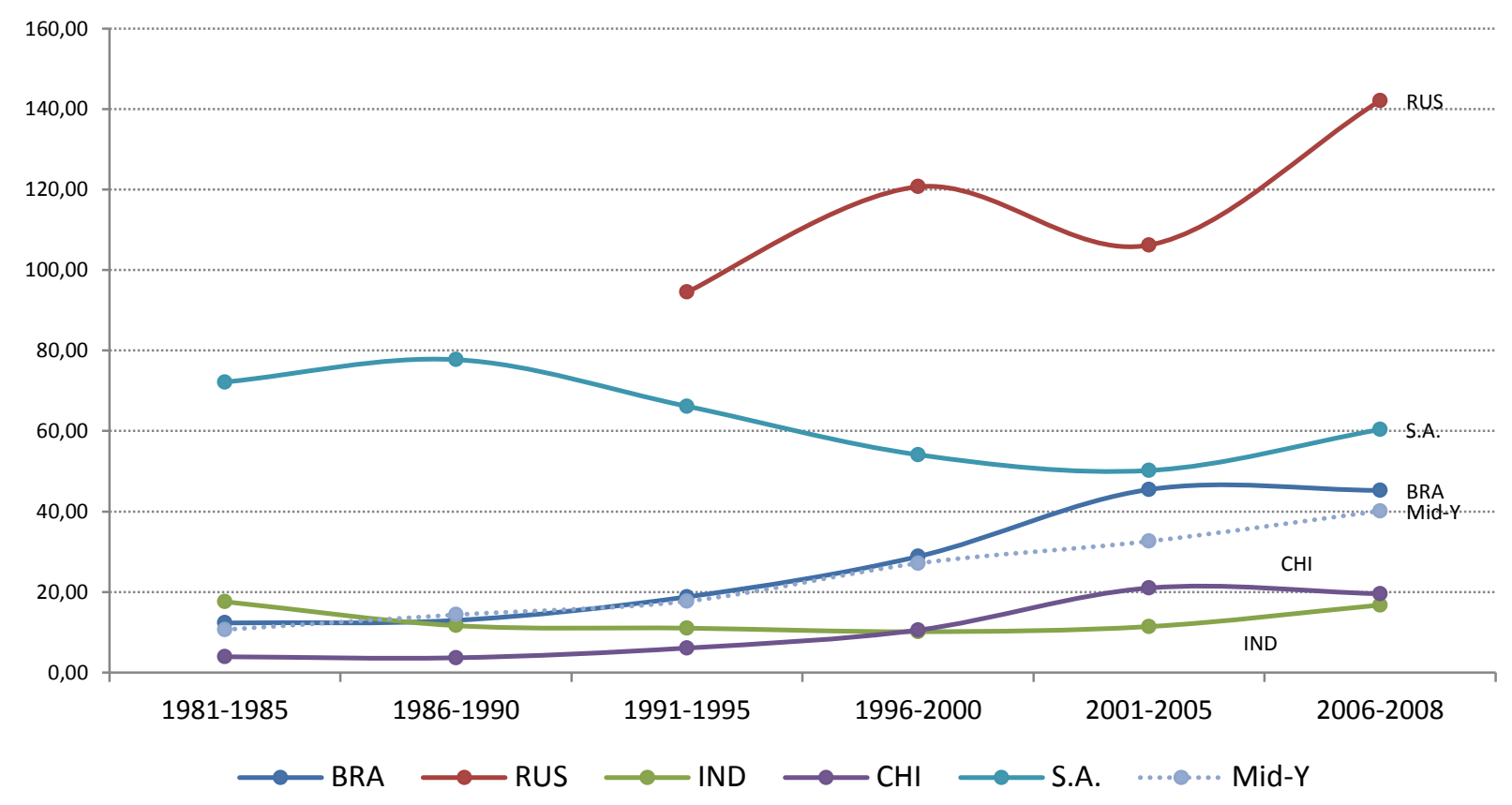

Source: Authors' estimations based on Castellacci and Natera (2011)

Investment in science and technological innovation is at the core of most of BRICS' industrial development strategies. Consider for instance that in Brazil public spending on science doubled between 2003 and 2010. In 2010 the country adopted an ambitious innovation policy that aims to increase total spending on science and technology further to 2 per cent of GDP by 2020. According to the country's minister for science, technology and innovation, 'Innovation is not an option, it is imperative' (Massarani, 2012). 


\subsection{The Contribution of MNEs}

The growing technological sophistication, rising labour productivity and patterns of growth and structural change discussed in the previous sections have been influenced by the extent to which BRICS have been integrated into the global economy through the actions of Multinational Enterprises (MNEs). The channels through which MNEs influence a host country's economy particularly technological catch-up - have been discussed in section 2 of this paper.

In this section we document the extent of MNE activity in BRICS. We measure this in two ways: (i) the amount and share of inward FDI going to these countries and (ii) the amount of FDI as a percentage of Gross Fixed Capital Formation (GFCF).

Figure 11 presents statistics on inward FDI flowing to BRICS in comparison to the total for middle-income countries.

Figure 11. BRICS share in Global Inward FDI compared to other Middle-Income economies, 1980-2010 (\%)

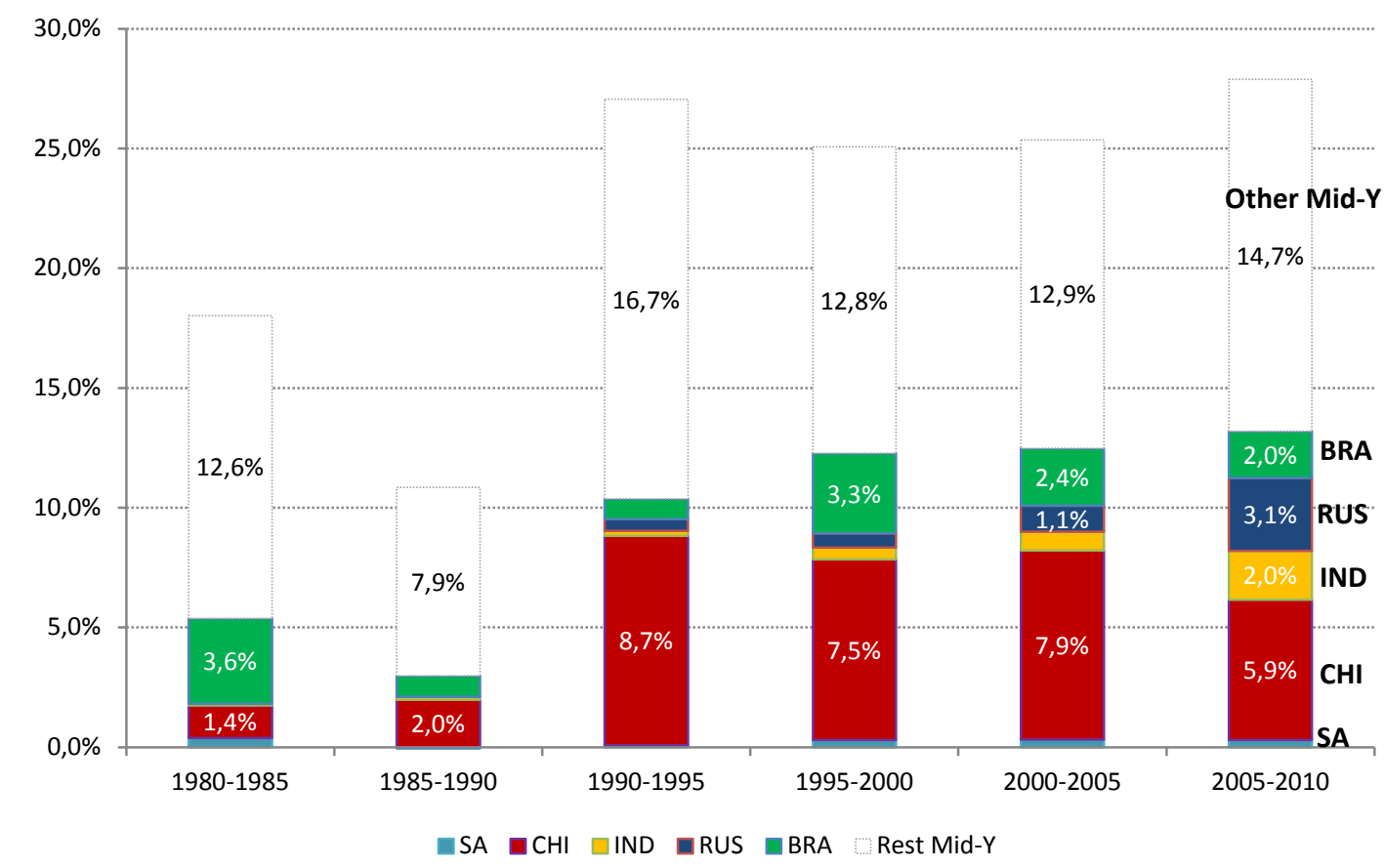

Source: Authors' estimations based on UNCTAD stats online

From Figure 11, it is clear that inward FDI may be potentially important to understand the patterns of growth and structural change that BRICS have achieved. Compared to middle income countries, BRICS are clearly increasing their share in total FDI. For instance in 1980 
BRICS received only 5 per cent of global FDI, while other middle-income countries already attracted 12 per cent. Thirty years later, BRICS account for 13 per cent of global FDI, while all other middle-income countries together account for only 15 per cent. Thus, most of the increase in the share of middle-income countries in global inward FDI has gone to BRICS. The bulk has gone to China - especially after the period 1985-1990, and to India and Russia especially in the period after 2005; Russia's oil-rich economy has attracted significant foreign investment. The share of FDI to Brazil peaked in 1995-2000. Whether this inflow of FDI has been significant is a hotly debated issue. It depends on the relationship with domestic investment, as well as the type of sectors to which FDI flowed. The share of South Africa, once important, has become negligible in 2005-2010.

In order to analyze the importance of FDI in Gross Fixed Capital Formation (GFCF) in each country we need to focus on Greenfield FDI. Greenfield investment is foreign investment that actually involves the creation of new capital facilities in the host economy (as opposed to the part of FDI which consists of mergers with and acquisitions of existing firms and activities). In Table 9a and 9b we present estimates on GFCF broken down into domestic investment and foreign Greenfield investment in three years 1987, 1997 and 2007, both in absolute terms and as percentage of GDP.

Table 9a. Gross Fixed Capital Formation, Domestic Investment and Greenfield FDI. BRICS 1987, 1997 and 2007 (in billions of current dollars)

\begin{tabular}{|c|c|c|c|c|c|c|c|c|c|c|c|c|c|c|c|}
\hline & \multicolumn{3}{|c|}{ Brazil } & \multicolumn{3}{|c|}{ Russia } & \multicolumn{3}{|c|}{ India } & \multicolumn{3}{|c|}{ China } & \multicolumn{3}{|c|}{ South Africa } \\
\hline & 1987 & 1997 & 2007 & 1987 & 1997 & 2007 & 1987 & 1997 & 2007 & 1987 & 1997 & 2007 & 1987 & 1997 & 2007 \\
\hline Domestic Inv. & 54.1 & 141.9 & 210.3 & - & 71.8 & 241.0 & 63.4 & 95.2 & 389.0 & 99.7 & 270.3 & $1,292.2$ & 15.3 & 23.1 & 56.3 \\
\hline $\begin{array}{l}\text { Green Field } \\
\text { FDI }\end{array}$ & 1.0 & 9.4 & 28.0 & - & 2.4 & 32.5 & 0.2 & 3.2 & 20.9 & 2.3 & 42.9 & 74.2 & 0.0 & 1.5 & 1.4 \\
\hline GFKF & 55.1 & 151.3 & 238.4 & - & 74.2 & 273.5 & 63.6 & 98.4 & 410.0 & 102.1 & 313.2 & $1,366.4$ & 15.3 & 24.6 & 57.7 \\
\hline
\end{tabular}

Source: Authors' estimations based on UNCTAD

Table 9b. Gross Fixed Capital Formation, Domestic Investment and Greenfield FDI, as \% of GDP. BRICS 5-year averages: 1986-1990, 1996-2000, 2006-2010

\begin{tabular}{|c|c|c|c|c|c|c|c|c|c|c|c|c|c|c|c|}
\hline & \multicolumn{3}{|c|}{ Brazil } & \multicolumn{3}{|c|}{ Russia } & \multicolumn{3}{|c|}{ India } & \multicolumn{3}{|c|}{ China } & \multicolumn{3}{|c|}{ South Africa } \\
\hline & $86-90$ & $95-01$ & $06-10$ & $86-90$ & $95-01$ & $06-10$ & $86-90$ & $95-01$ & $06-10$ & $86-90$ & $95-01$ & $06-10$ & $86-90$ & $95-01$ & $06-10$ \\
\hline Domestic Inv. & $22.1 \%$ & $14.9 \%$ & $15.8 \%$ & - & $16.3 \%$ & $18.4 \%$ & $23.7 \%$ & $23.1 \%$ & $30.9 \%$ & $27.2 \%$ & $29.8 \%$ & $40.3 \%$ & $19.1 \%$ & $15.5 \%$ & $20.4 \%$ \\
\hline Green Field FDI & $0.5 \%$ & $1.8 \%$ & $1.9 \%$ & - & $0.9 \%$ & $2.7 \%$ & $0.1 \%$ & $0.6 \%$ & $1.8 \%$ & $0.8 \%$ & $3.2 \%$ & $2.0 \%$ & $0.0 \%$ & $0.5 \%$ & $0.3 \%$ \\
\hline GFKF & $22.6 \%$ & $16.7 \%$ & $17.7 \%$ & - & $17.2 \%$ & $21.2 \%$ & $23.8 \%$ & $23.7 \%$ & $32.8 \%$ & $28.0 \%$ & $33.0 \%$ & $42.3 \%$ & $19.2 \%$ & $16.0 \%$ & $20.7 \%$ \\
\hline
\end{tabular}

Source: Authors' estimations based on UNCTAD

As we can see, with the exception of Brazil, all countries show an increasing trend in their ratio of GFCF to GDP. The most impressive increase is found in China (which reaches $42.3 \%$ of GDP in 
2007), followed by India (32.8\%). In all cases, it is interesting to notice that most of this increase driven by large increases in domestic investment rather than foreign Greenfield investment.

To better capture the relationship between domestic and foreign investment in GFCF, Figure 12 depicts the share of Greenfield FDI in GFCF in each of BRICS and in the remaining middle income economies.

Figure 12. Greenfield FDI as \% of Gross Fixed Capital Formation (5 year averages). BRICS countries and other middle-income economies. 1986-2010

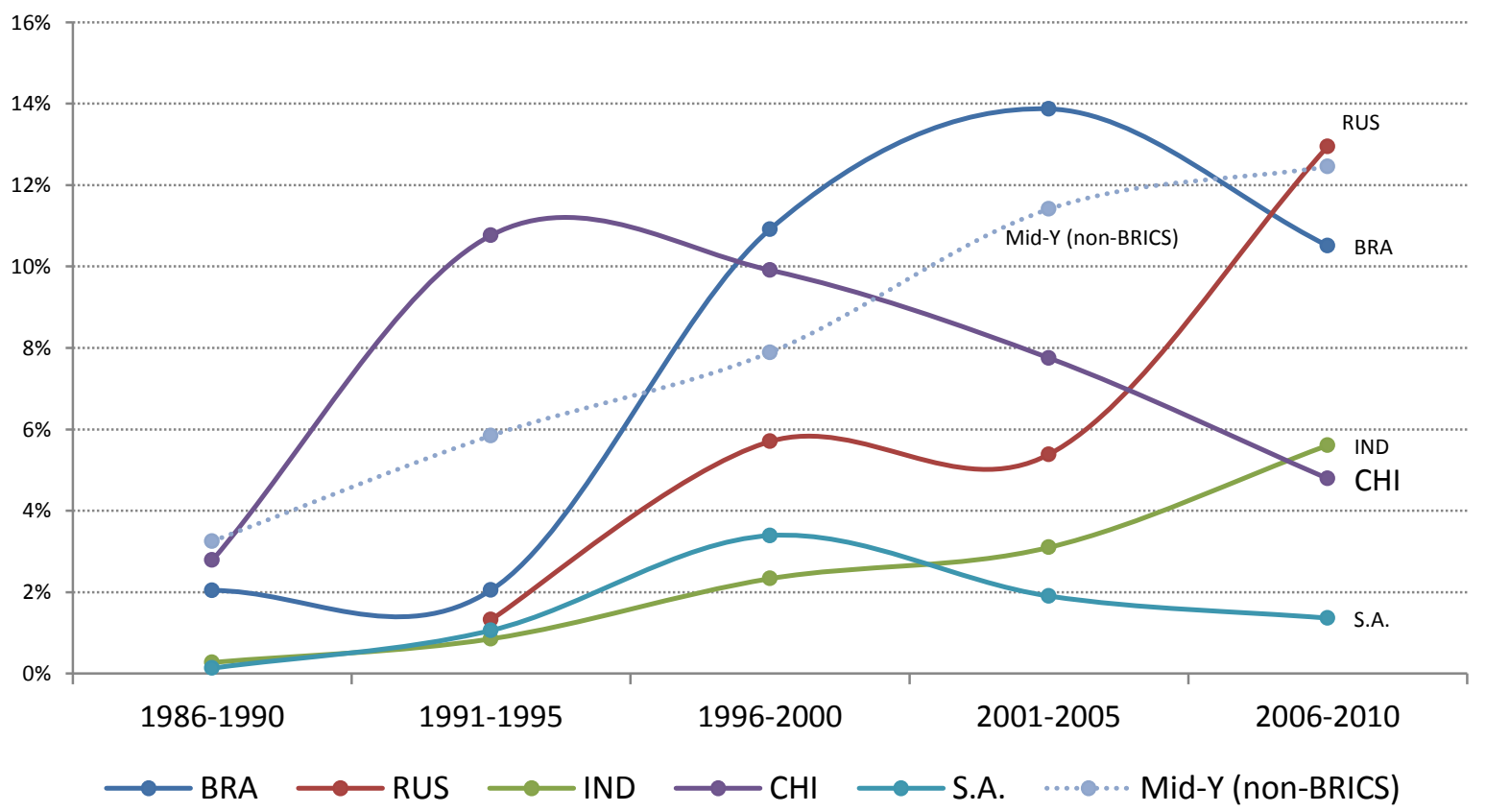

Source: Authors' estimations based on UNCTAD stats online

In terms of trends we see two different patterns. In Brazil, China and South Africa, we see an initial increase in the share of foreign investment, followed by a decline. In Russia and India we see a sustained increase in the importance of FDI in total investment. In terms of levels, FDI is most important in the most recent period in Russia and Brazil, least important in South Africa. In the period 2006-10, the middle income countries have higher dependence on foreign investment than the BRICS with the exception of Russia.

It would seem that sustained growth and structural transformation accompanied or driven by technological transfer may require inflows of FDI, but may also need strong growth in domestic fixed investment. It is worth noting that the contribution of FDI to total capital formation is 
substantial in all countries except South Africa (between 5 and 13 per cent). 13 But the overwhelming part of gross fixed capital formation derives from domestic investment.

Secondly, we need to consider the sectoral destination of FDI. Table 10 shows 5 -year averages of the distribution by major sectors of total FDI going into the BRICS countries in three timeintervals 14 .

Table 10. Sectoral Distribution of Total FDI. BRICS, 5 year averages in different time-intervals (in \%)

\begin{tabular}{|c|c|c|c|c|c|c|c|c|c|c|c|c|c|c|c|}
\hline & \multicolumn{3}{|c|}{ Brazil } & \multicolumn{3}{|c|}{ Russia } & \multicolumn{3}{|c|}{ India } & \multicolumn{3}{|c|}{ China } & \multicolumn{3}{|c|}{ South Africa } \\
\hline Agriculture & $0.6 \%$ & $0.3 \%$ & $1.5 \%$ & - & $0.5 \%$ & $1.9 \%$ & $9.6 \%$ & $2.7 \%$ & $0.3 \%$ & $2.2 \%$ & $1.5 \%$ & $1.3 \%$ & - & $0.3 \%$ & $0.1 \%$ \\
\hline Mining & $2.9 \%$ & $1.4 \%$ & $14.8 \%$ & - & $12.4 \%$ & $29.8 \%$ & $0.4 \%$ & $0.3 \%$ & $0.8 \%$ & $24.4 \%$ & $1.7 \%$ & $0.6 \%$ & - & $16.1 \%$ & $36.7 \%$ \\
\hline Manufacturing & $73.8 \%$ & $18.1 \%$ & $36.8 \%$ & - & $35.1 \%$ & $26.4 \%$ & $86.6 \%$ & $61.2 \%$ & $27.3 \%$ & $37.3 \%$ & $59.7 \%$ & $56.0 \%$ & - & $35.4 \%$ & $28.1 \%$ \\
\hline Utilities & $0.0 \%$ & $15.0 \%$ & $4.5 \%$ & - & $0.0 \%$ & $2.3 \%$ & $0.0 \%$ & $5.5 \%$ & $4.5 \%$ & $7.2 \%$ & $6.9 \%$ & $2.3 \%$ & - & $0.0 \%$ & $0.0 \%$ \\
\hline Services & $22.6 \%$ & $64.7 \%$ & $38.7 \%$ & - & $49.3 \%$ & $35.6 \%$ & $3.4 \%$ & $28.3 \%$ & $59.4 \%$ & $27.4 \%$ & $27.3 \%$ & $38.8 \%$ & - & $47.9 \%$ & $34.8 \%$ \\
\hline Trade... (1) & $4.1 \%$ & $8.1 \%$ & $8.5 \%$ & - & $14.6 \%$ & $9.8 \%$ & - & $2.6 \%$ & $4.3 \%$ & $3.1 \%$ & $2.7 \%$ & $5.5 \%$ & - & $7.6 \%$ & $3.9 \%$ \\
\hline Transport... (2) & $0.2 \%$ & $18.8 \%$ & $4.6 \%$ & - & $7.9 \%$ & $3.5 \%$ & - & $10.6 \%$ & $7.9 \%$ & $2.4 \%$ & $3.4 \%$ & $2.9 \%$ & - & $3.7 \%$ & $5.0 \%$ \\
\hline Financing... (3) & $16.5 \%$ & $37.4 \%$ & $25.2 \%$ & - & $18.2 \%$ & $21.6 \%$ & - & $13.9 \%$ & $40.4 \%$ & $22.0 \%$ & $16.0 \%$ & $28.9 \%$ & - & $36.6 \%$ & $25.9 \%$ \\
\hline
\end{tabular}

Source: Authors' estimations based on country specific sources (see Appendix)

(1) Trade, restaurants and hotels

(2) Transport and telecommunications

(3) Financing, Real Estate and Business

With the exception of South Africa, all BRICS show an increased importance of Finance, Real Estate and Business services as a destination of FDI. In Brazil, Russia and South Africa one sees a reorientation of FDI over time from manufacturing towards mining. That is, FDI seems to be increasingly orientated to the exploitation of natural resources, and thus - from a pessimistic perspective on resource-based development - less conducive to sustained economic growth and structural transformation.

The opposite seems to be true for China, where the share of mining in total FDI drops dramatically (from $25 \%$ in the 1980 s to less than $1 \%$ in the 2000 s), while the manufacturing

13 From the perspective of technology transfer total FDI including mergers and acquisitions is also of interest. In China most investment is Greenfield investment. The same is true for most other countries. The exception is South Africa where between 2007 and 2009 Greenfield investment is only a small portion (20-30 percent) of total FDI.

14 The following tables refer to the distribution of total FDI (green fields plus mergers and acquisitions). Unfortunately data on sectoral distribution of green field FDI is rarely available. 
sector gains importance over time. This trend in investment has supported the structural changes in sectoral output and exports that we have described earlier.

In contrast to China, India shows a very large decline in the share of FDI going to manufacturing. But in this case the bulk of FDI has flowed into the service sector, in particular finance, real estate and business services. This is again consistent with the structural change of this economy towards services previously described.

Within the manufacturing sector, the various sectoral destinations of inward FDI are shown in Table 11.

Table 11. Sectoral Distribution of FDI within BRICS, 5 year averages in different time-intervals (in \% of manufacturing FDI)

\begin{tabular}{|c|c|c|c|c|c|c|c|c|c|c|c|c|c|c|c|}
\hline & \multicolumn{3}{|c|}{ Brazil } & \multicolumn{3}{|c|}{ Russia } & \multicolumn{3}{|c|}{ India } & \multicolumn{3}{|c|}{ China } & \multicolumn{3}{|c|}{ South Africa } \\
\hline & $81-85$ & $96-00$ & $06-10$ & $81-85$ & $96-00$ & $06-10$ & $86-90$ & $95-99$ & $06-10$ & $84-88$ & $00-05$ & $06-10$ & $81-85$ & $96-00$ & 01-05 \\
\hline Food, beverages and tobacco & $10.5 \%$ & $18.5 \%$ & $10.9 \%$ & - & $63.8 \%$ & $15.8 \%$ & $7.0 \%$ & $10.9 \%$ & $4.9 \%$ & - & $6.2 \%$ & $9.3 \%$ & - & $31.0 \%$ & $17.7 \%$ \\
\hline Textiles and textiles products & $0.8 \%$ & $2.0 \%$ & $2.0 \%$ & - & $1.5 \%$ & $0.9 \%$ & $4.0 \%$ & $3.6 \%$ & $2.5 \%$ & - & $4.8 \%$ & $2.5 \%$ & - & $0.0 \%$ & $0.0 \%$ \\
\hline Leather, leather and footwear & $1.4 \%$ & $0.2 \%$ & $0.7 \%$ & - & $0.0 \%$ & $0.0 \%$ & $0.0 \%$ & $0.5 \%$ & $0.2 \%$ & - & $3.1 \%$ & $2.3 \%$ & - & $0.0 \%$ & $0.0 \%$ \\
\hline $\begin{array}{l}\text { Wood and products of wood } \\
\text { and cork }\end{array}$ & $2.3 \%$ & $0.9 \%$ & $0.9 \%$ & - & $0.0 \%$ & $7.7 \%$ & $0.0 \%$ & $0.0 \%$ & $0.0 \%$ & - & $0.6 \%$ & $0.3 \%$ & - & $0.0 \%$ & $0.0 \%$ \\
\hline $\begin{array}{l}\text { Pulp, paper, paper products } \\
\text { and publishing }\end{array}$ & $3.2 \%$ & $0.9 \%$ & $9.5 \%$ & - & $11.1 \%$ & $6.0 \%$ & $0.0 \%$ & $3.8 \%$ & $2.4 \%$ & - & $8.4 \%$ & $3.5 \%$ & - & $0.8 \%$ & $8.1 \%$ \\
\hline $\begin{array}{l}\text { Coke, refined petroleum } \\
\text { products, nuclear fuel }\end{array}$ & $9.2 \%$ & $0.2 \%$ & $9.1 \%$ & - & $0.0 \%$ & $0.2 \%$ & $0.0 \%$ & $6.6 \%$ & $7.7 \%$ & - & $3.4 \%$ & $3.9 \%$ & - & $0.0 \%$ & $0.0 \%$ \\
\hline $\begin{array}{l}\text { Chemicals and chemical } \\
\text { products }\end{array}$ & $16.4 \%$ & $16.7 \%$ & $9.1 \%$ & - & $3.8 \%$ & $8.7 \%$ & $33.5 \%$ & $21.7 \%$ & $14.7 \%$ & - & $10.1 \%$ & $14.3 \%$ & - & $16.6 \%$ & $1.9 \%$ \\
\hline Rubber and plastics products & $3.6 \%$ & $3.2 \%$ & $3.6 \%$ & - & $0.0 \%$ & $5.5 \%$ & $0.0 \%$ & $1.3 \%$ & $0.5 \%$ & - & $5.8 \%$ & $3.8 \%$ & - & $0.0 \%$ & $0.0 \%$ \\
\hline $\begin{array}{l}\text { Other non-metallic mineral } \\
\text { products }\end{array}$ & $1.7 \%$ & $6.1 \%$ & $2.6 \%$ & - & $6.1 \%$ & $13.1 \%$ & $0.0 \%$ & $3.9 \%$ & $8.7 \%$ & - & $3.3 \%$ & $4.5 \%$ & - & $0.0 \%$ & $0.0 \%$ \\
\hline $\begin{array}{l}\text { Basic metals and metal } \\
\text { products }\end{array}$ & $9.3 \%$ & $3.7 \%$ & $31.7 \%$ & - & $3.6 \%$ & $10.2 \%$ & $6.1 \%$ & $2.2 \%$ & $13.5 \%$ & - & $6.6 \%$ & $11.1 \%$ & - & $12.8 \%$ & $23.7 \%$ \\
\hline Machinery NEC & $11.0 \%$ & $7.4 \%$ & $4.1 \%$ & - & $9.9 \%$ & $8.9 \%$ & $15.4 \%$ & $7.4 \%$ & $8.3 \%$ & - & $6.2 \%$ & $7.9 \%$ & - & $0.0 \%$ & $0.0 \%$ \\
\hline $\begin{array}{l}\text { Electrical and optical } \\
\text { equipment }\end{array}$ & $9.8 \%$ & $15.7 \%$ & $5.3 \%$ & - & $0.0 \%$ & $8.0 \%$ & $12.8 \%$ & $15.7 \%$ & $8.3 \%$ & - & $29.7 \%$ & $23.8 \%$ & - & $0.0 \%$ & $0.0 \%$ \\
\hline Transport equipment & $18.4 \%$ & $23.0 \%$ & $9.6 \%$ & - & $0.0 \%$ & $13.2 \%$ & $12.3 \%$ & $22.1 \%$ & $22.5 \%$ & - & $9.7 \%$ & $11.5 \%$ & - & $38.8 \%$ & $48.7 \%$ \\
\hline $\begin{array}{l}\text { Furniture, manufacturing } \\
\text { n.e.c. and recycling }\end{array}$ & $2.4 \%$ & $1.2 \%$ & $0.7 \%$ & - & $0.0 \%$ & $1.6 \%$ & $8.8 \%$ & $0.4 \%$ & $5.6 \%$ & - & $2.2 \%$ & $1.3 \%$ & - & $0.0 \%$ & $0.0 \%$ \\
\hline Total & $100 \%$ & $100 \%$ & $100 \%$ & - & $100 \%$ & $100 \%$ & $100 \%$ & $100 \%$ & $100 \%$ & - & $100 \%$ & $100 \%$ & - & $100 \%$ & $100 \%$ \\
\hline
\end{tabular}

Source: Authors' estimations based on country specific sources (see Appendix)

Given the wide range of sources used to construct Table 11, the comparability of FDI structures between countries is quite limited, and thus, we should analyze the data in this table with caution. Nevertheless, some general patterns can be observed. In Brazil and South Africa, FDI is mainly concentrated in four sectors: Food, Chemicals, Basic Metals and Transport equipment. In South Africa, the latter sector is much more important than in Brazil. 
Russia follows a similar pattern: Food products and Transport equipment are the major recipients of FDI, along with non-metallic mineral products.

Finally, China and India share with the other BRICS a high share of FDI in Chemicals and Transport equipment, but also show large inflows of FDI into Machinery and Electrical and optical equipment (e.g. Apple's assembly operations).

\section{Summary and Conclusions}

In this paper we have asked what other countries can learn from the BRICS about how to achieve structural change, industrialization and technological upgrading and how foreign and domestic sources of technology contribute to such developments. We first documented the "rise" of BRICS; then described the extent of their industrialization with particular emphasis on the changes within manufacturing. We also examined the patterns of science, technological change and innovation, and the contributions and patterns of FDI and domestic investment.

We can summarize our findings in the form of a few 'stylized' facts.

Firstly, in terms of the patterns of structural change we established that

- China and India's rapid growth of per capita has been accompanied by structural changes away from agriculture, and into manufacturing and services, respectively. Within manufacturing, structural change has taken place away from labour intensive manufacturing towards more capital (and technological/skill) intensive production.

- In Russia, rapid growth since 1997 has not been accompanied by a growing share of manufacturing in GDP. On the contrary, the manufacturing sector's share in value added shrank most in Russia - by almost 3 percentage points between 1995 and 2008. Nevertheless, in terms of growth and level of GDP per capita Russia has performed rather well. Much of this growth however is a natural resource based recovery from the post 1989 slump. In the long run Russia has been quite stagnant.

- The other resource-rich economy - South Africa - has likewise experienced a shrinking manufacturing share - but surprisingly an even larger decline in the relative share of mining, over a period that includes one of the strongest commodity booms since the Second World War. South Africa has become a service economy with services accounting for two thirds of GDP in 2008.

Secondly, as far as science and technological upgrading is concerned, 
- Over the period 1980 to $2006, R \& D$ spending exceeded the mean increase in R\&D spending of middle-income countries. The most significant growth in R\&D has been in China (especially since 1996) and in India (although the level of R\&D in the latter country is still the lowest of all the BRICS).

- It is noticeable that in the case of Brazil, Russia and South Africa R\&D expenditure has been stagnating (even declining since 2001 in Russia). It is also striking that gap with respect to the US is still very substantial.

- In terms of patents registered in the US, substantial progress has been made in China, where, unlike in the other countries, the growth in the number of patents registered shows no sign of slowing down. Russia, Brazil and South Africa have seen a decline in patents since 2000, with South Africa perhaps the worst performer. By the early 1980s South Africa was second only to Russia with regard to patent registrations, but by 2008 it was producing the least number of new patents.

- The number of scientific papers published per head population differs substantially, with some progress in Brazil, India and China, and with Russia standing out as the most productive country in this respect. South Africa, in contrast has experienced a sharp decline in scientific publishing since the early 1990s, consistent with the general decline in scientific and technological upgrading in the country reflected in the other indicators.

In sum, technological progress has been most significant in China, followed by India, and by a lesser extent in Brazil, Russia and South Africa. The latter two remain economies that are essentially dominated by natural resource extraction and services, and by difficulties in their political and social transition processes.

One possible explanation for disparate technological progress may be the success and relative failures of the various countries' educational policies. China and India stand out from the other countries in terms of the success of higher education - in turning out and attracting highly skilled labour. Brazil, Russia, China and India are indeed amongst the top five countries in the world in terms of the absolute number of university enrolments in 2007 (Fu et al., 2010). In addition to investments in human capital, increased domestic investment in infrastructure, efforts to attract return migration of skilled workers (Altenburg et al., 2008), policies to transfer surplus labour from rural to urban areas, and the practice of requiring joint ventures (JVs) with foreign companies (Harrison and Rodriguez-Clare, 2010) played a highly significant role in making technology transfers from MNEs more effective in China. This accelerated the structural transformation China (and to a lesser extent India) which in turned made these economies even more attractive as a destination for foreign investment and for the rising trend of global R\&D. 
In contrast, South Africa, the science and technology laggard is widely seen as being hampered by a lack of skilled workers, and experiencing a significant brain drain. As we show further this has been accompanied by a decline in the share of domestic investment in gross fixed capital formation in the economy. It is difficult to see how this country's Industrial Policy Action Plan (IPAP) can be successful as long as the weak performance of the country's educational sector and the outflow of skilled labour (driven additionally by high crime rates and spiralling corruption) are not rectified.

Thirdly, as far as the role of FDI is concerned, we established that

- The largest chunk of FDI goes to China - especially after the period 1985 to 1990 and to India and Russia - especially in the period after 2005. FDI has driven China's export led growth as well as industrialization, with most FDI to China flowing into manufacturing sectors. In Brazil, Russia and South Africa there has been a reorientation of FDI over time, from manufacturing towards mining.

- India shows an impressive decline in the share of FDI going to manufacturing. In this case the bulk of FDI has flowed into the service sector, in particular financing, real estate and business services.

- In Brazil, Russia, India and South Africa FDI is increasingly orientated to either the exploitation of natural resources or service activities, or thus, less becoming less conducive to manufacturing and industrialization.

- BRICS show an increasing trend in their ratios of Gross Fixed Capital Formation (GFCF) to GDP. The most impressive increases were again found in China.

In light of the above we can conclude that the most significant difference between the most successful country China, and the other BRICS, is the degree to which domestic investments and initiatives have succeeded in channelling FDI and its technological benefits towards the manufacturing sector.

Finally, a big challenge remains for the BRICS. Much still needs to be done to facilitate technological upgrading. A significant technological gap remains, also in the leader, China. 


\section{Acknowledgement}

This paper is derived from a background paper prepared by the authors for the UNIDO report: "Structural Change, Poverty Reduction and Industrial Policy in the BRICS", Vienna: UNIDO and UNU-MERIT, 2012. The full UNIDO Report is available at http://institute.unido.org/documents/M1 Home/BRICS report.pdf. We are grateful to the participants at the UNIDO Workshop on this topic held on 16-17 August 2012 in Vienna, in particular to Ludovico Alcorta and Nobuya Haraguchi, for their constructive comments.

\section{References}

Abramovitz, M. (1989b). 'Thinking about Growth', in: M. Abramovitz, Thinking about Growth and other Essays on Economic Growth and Welfare, Cambridge: Cambridge University Press, pp. 3-79.

Ács, Z. and Naudé, W.A. (2013). 'Entrepreneurship, Stages of Development, and Industrialization', (In Szirmai, A., Naudé, W.A. and Alcorta, L. eds. Pathways to Industrialization in the Twenty First Century. Oxford: Oxford University Press.)

Aitken, B.J. and Harrison, A.E. (1999). 'Do Domestic Firms Benefit from Direct Foreign Investment? Evidence from Venezuela', American Economic Review, 89: 605-618.

Alfaro, L. and Charlton, A. (2008). "Growth and the Quality of Foreign Direct Investment: Is all FDI Equal?" CEP Discussion Paper no. 830.

Alfaro, L. and Rodriguez-Clare, A. (2004). 'Multinationals and Linkages: An Empirical Investigation', Economia, Spring 4(2).

Alfaro, L., Chandra, V., Kalemli-Ozcan, S. and Sayek, S. (2004). 'FDI and Economic Growth: The Role of Local Financial Markets', Journal of International Economics, 64 (1): 89-112.

Altenburg, T. (2006). 'Governance Patterns in Value Chains and their Development Impact', European Journal of Development Research, 18 (4): 498-521.

Altenburg, T., Schmitz, H. and Stamm, A. (2008). 'Breakthrough? China's and India's Transition from Production to Innovation', World Development, 36 (2): 325-344. 
Amsden A. H. (2011), 'Firm Ownership and Entrepreneurship', in A. Szirmai, W. Naudé and M. Goedhuys (eds), Entrepreneurship, Innovation and Development, Oxford, Oxford University Press, pp.

Athukorala,P.C. and Menon, J. (2010), 'Global Production Sharing Patterns and Determinants of Trade Flows in East Asia', ADB Working Paper Series on Regional Integration no. 41, Asian Development Bank.

Baldwin, R. E. (2003). 'Openness and Growth: What's the Empirical Relationship?' Working Paper 9578. Cambridge, MA: National Bureau for Economic Research.

Baldwin, R.E. (2011). 'Trade and Industrialization after Globalization's 2nd Unbundling: How Building and Joining a Supply Chain are Different and Why it Matters', NBER Working Paper no. 17716.

Blalock, G. and Gertler, P. (2003). Technology from Foreign Direct Investment and Welfare Gains through the Supply Chain. Mimeo: Cornell University.

Blomström, M. and Kokko, A. (1998). 'Multinational Corporations and Spillovers', Journal of Economic Surveys, 12 (3): 247-277.

Blonigen, B. and Wang, M (2005). 'Inappropriate Pooling of Wealthy and Poor Countries in Empirical Studies? Does Foreign Direct Investment Accelerate Economic Growth? Institute for International Economics: Center for Global Development.

Borenzstein, E., De Gregorio, J. and Lee, J.W. (1998). 'How Does Foreign Direct Investment Affect Economic Growth?' Journal of International Economics, 45: 115-135.

Bournakis, I., M. Vecchi, and F. Venturi (2011). 'Offshoring and Specialization: Are Industries Moving Abroad?', Quaderno no. 98, December.

Broadman, H. G. and X. Sun, (1997). 'The distribution of foreign direct investment in China', Policy Research Working Paper Series 1720, The World Bank.

Carlsson, B. (2006). 'Internationalization of Innovative Systems: A Survey of the Literature', Research Policy, 35: 56-67.

Castellaci, F. and Archibugi, D. (2008). 'The Technology Clubs: The Distribution of Knowledge Across Nations', Research Policy, 37 (10): 1659-1673.

Castellani, D. and Zanfei, A. (2002). Technology Gaps, Absorptive Capacity and the Impact of Inward Investments on Productivity of European Firms. Mimeo: University of Urbino. 
Castellacci, F. and Natera, J.M. (2011). A new panel dataset for cross-country analyses of national systems, growth and development (CANA).

Chandra, V. and Kolavalli, S. (2006). "Technology, Adaptation and Exports: How Some Countries Got it Right"(In Chandra, V. ed. Technology, Adaptation and Exports. Washington DC: The World Bank).

Chang, S.J., Chung, J. and Xu, D. (2007). 'FDI and Technology Spillovers in China', CEI Working Paper Series 2007-7.

Chen, S., Jefferson, G.H. and Zhang, J. (2011). 'Structural Change, Productivity Growth and Industrial Transformation in China", China Economic Review, 22: 133-150.

Chenery, H. B. (1960). 'Patterns of Industrial Growth'. American Economic Review, 50 (4): 62454.

Chuang, Y.C. and Hsu, P.F. (2004). 'FDI, Trade and Spillover Efficiency: Evidence from China's Manufacturing Sector", Applied Economics, 36 (10): 1103-

Cimoli, M., G. Dosi, R. Nelson, and J. Stiglitz (2006). 'Institutions and Policies Shaping Industrial Development. An Introductory Note'. Paper prepared for the task force on Industrial Policies and Development. New York: Columbia University.

Coxhead, I. and Jayasuriya, S. (2010). 'China, India and the Commodity Boom: Economic and Environmental Implications for Low-Income Countries', The World Economy, 525-551.

De Vries, G., Erumban, A., Timmer, M., Voskoboynikov, I., and H. Wu (2012). 'Deconstructing the BRICs: Structural transformation and aggregate productivity growth', Journal of Comparative Economics, Volume 40, Issue 2, May 2012, Pages 211-227.

Dosi, G. (1982). 'Technological Paradigms and Technological Trajectories: The Determinants and Directions of Technical Change and the Transformation of the Economy', Research Policy, 11 (3): 147-162.

Du, L., Harrison, A. and Jefferson, G. (2008). 'Testing for Horizontal and Vertical Foreign Investment Spillovers in China', Working Paper, University of California at Berkeley.

Dunning, J. and Narula, R. (2000). 'Industrial Development, Globalization and Multinational Enterprises: New Realities for Developing Countries', Oxford Development Studies, 28 (2): 141167. 
Eaton, J. and Kortum, S. (1999). 'International Technology Diffusion: Theory and Measurement", International Economic Review, 40 (3): 537 -

Eaton, J. and Kortum, S. (2001).'Technology, Trade and Growth: A Unified Framework', European Economic Review, 45: 742-755.

Eberhardt, M., Helmers, C. and Yu, Z. (2011). 'Is the Dragon Learning to Fly? An Analysis of the Chinese Patent Explosion', CSAE Working Paper WPS/2011-15. University of Oxford.

Economist, The (2012). 'The masala Mittelstand: Manufacturing is taking off in India. But not in the way many hoped', The Economist, 11 August 2012 online at http://www.economist.com/node/21560263?frsc=dg|a

Fagerberg J. and M.M. Godinho (2005). 'Introduction', in. J. Fagerberg, D.C. Mowery and R.R. Nelson (eds) (2005) The Oxford Handbook of Innovation, Oxford: Oxford University Press, pp. 514-542.

Fagerberg, J., Shrolec, M. and Verspagen, B. (2010). 'Innovation and Economic Development' (In Handbooks in Economics, vol 2, chapter 20, pp. 834-871).

Fagerberg, J., M. Srholec, and M. Knell (2007). 'The Competitiveness of Nations: Why Some Countries Prosper while Others Fall Behind', World Development, 35 (10): 1595-620.

Feenstra, R. (1998). 'Integration of Trade and Disintegration of Production in the Global Economy', Journal of Economic Perspectives, 14 (4). 31-50.

Figueirdo, P. (2007). 'Industrial Policy Changes and Firm-Level Technological Capability Development: Evidence from Northern Brazil', World Development, 36 (1): 55-88.

Fischer, W.A. and Von Zedtwitz, M. (2004). 'Chinese R\&D: Naissance, Renaissance or Mirage?”, R\&D Management, 34 (4): 349-365.

Fong, H.D. (1942). 'The Prospects for China's Industrialization', Pacific Affairs, 15 (1): 44-60.

Franco, E., Ray, S. and Ray, P.K. (2011). 'Patterns of Innovation Practices of MultinationalAffiliates in Emerging Economies: Evidence from Brazil and India', World Development, 39(7): 1249-1260.

Fu, X., Pietrobelli, C. and Soete, L. (2010). 'The Role of Foreign Technology and Indigenous Innovation in the Emerging Economies: Technological Change and Catching-up', World Development, 39 (7): 1204-1212. 
Gerschenkron, A. (1982). Economic Backwardness in Historical Perspective. Cambridge MA: Harvard University Press.

Gimet, C., B. Guilhon and N. Roux (2010). 'Fragmentation and Immiserising Specialization: The Case of the Textile and Clothing Sector', Working Paper 1003, Groupe D'Analyse et de Theorie Economique Lyon - St Etienne. March.

Girma, S., Gong, Y. and Görg, H. (2009). 'What Determines Innovation Activity in Chinese StateOwned Enterprises? The Role of Foreign Direct Investment', World Development, 37 (4): 866873.

Görg, H. and Greenaway, D. (2004). 'Much Ado about Nothing? Do Domestic Firms Really Benefit from Foreign Direct Investment?', The World Bank Research Observer, 19 (2): 171-197.

Görg, H. and Strobl, E. (2002). 'Multinational Companies and Indigenous Development: An Empirical Analysis', European Economic Review, 46: 1305-132.

Grossman, G.M. and E. Rossi-Hansberg (2008). 'Trading Tasks: A Simple Theory of Offshoring', American Economic Review, 98 (5): 1978-1997.

Grossman, G.M. and Helpman, E. (2005). 'Outsourcing in a Global Economy', Review of Economic Studies, 72 (1). 135-159.

Hale, G. and Long, C. (2007). 'Are There Productivity Spillovers from Foreign Direct Investment in China?", Pacific Economic Review, 16 (2): 135-153.

Harrison, A. and Rodríguez-Clare, A. (2010). 'Trade, Foreign Investment, and Industrial Policy for Developing Countries', Chapter 63 of the Handbook of Development Economics, volume 5, pp. 4039-4214.

Haskel, J.E., Pereira, S.C. and Slaughter, M.J. (2007). 'Does Inward Foreign Direct Investment Boost Productivity of Domestic Firms?' The Review of Economics and Statistics, 89 (3): 482-496.

Hausmann, R., Hwang, J. and Rodrik, D. (2007). 'What You Export Matter', Journal of Economic Growth, 12 (1): 1-25.

Hobday, M. (1994). 'Export-Led Technology Development in the Four Tigers: The Case of Electronics', Development and Change, 25 (2): 333-361.

Houseman, S., Kurz, C., Lengermann, P. and Mandel, B. (2010). 'Offshoring and the State of American Manufacturing', UPJohn Institute Working Paper no. 10-166. 
Hsieh, C-T. and Klenow, P. (2009). 'Misallocation and Manufacturing TFP in China and India', The Quarterly Journal of Economics, 124 (4): 1403-1448.

Hu, G.A. (2010). 'Propensity to Patent, Competition and China's Foreign Patenting Surge', Research Policy, 39: 985-993.

Hu, G.A. , Jefferson, G. and Jinchung, Q. (2005). 'R\&D and Technology Transfer: Firm-Level Evidence from Chinese Industry', Review of Economics and Statistics, 87 (4): 780-786.

Hu, G.A. and Jefferson, G. (2002). 'FDI Impact and Spillover: Evidence from China's Electronic and Textile Industries', The World Economy, 25: 1063-1076.

Hu, G.A. and Jefferson, G. (2008). 'Science and Technology in China', (In Brandt, L. and Rawski, T. eds. China's Great Economic Transformation. New York: Cambridge University Press).

Hu, M-C. and Mathews, J.A. (2008). 'China's National Innovative Capacity', Research Policy, 37 (9): 1465-1479.

Hummels, D., J. Ishii and K. Yi (2001). 'The Nature and Growth of Vertical Specialization in World Trade', Journal of International Economics, 54:75-96.

Iwasaki, I. and K. Suganuma (2005): 'Regional Distribution of Foreign Direct Investment in Russia', Post-Communist Economies, 17:2, 153-172

Javorcik, B.S. (2004). 'Does Foreign Direct Investment Increase Productivity of Domestic Firms? In Search of Spillovers through Backward Linkages', American Economic Review, 94 (3):

Jefferson, G., Hu, G.A., Guan, X. and Yu, X. (2003). 'Ownership, Performance and Innovation in China's Large-and Medium-Size Industrial Enterprise Sector', China Economic Review, 14 (1): 89113.

Kaplinsky, R. (2011). 'Commodities for Industrial Development: Making Linkages Work', Development Policy, Statistics and Research Branch Working Paper 01/2011, UNIDO.

Kathuria, V. (2000). 'Productivity Spillovers from Technology Transfer to Indian Manufacturing Firms', Journal of International Development, 12: 343-369.

Keller, W. (2004). 'International Technology Diffusion”, Journal of Economic Literature, 42: 752782.

Kemeny, T. (2009). 'Are InternationalTechnology Gaps Growing or Shrinking in the Age of Globalization?', Journal of Economic Geography, 
Kemeny, T. (2010). 'Does Foreign Direct Investment Drive Technological Upgrading?' World Development, 38 (11): 1543-1554.

Konings, J. (2001). 'The Effects of Foreign Direct Investment on Domestic Firms: Evidence from Firm Level Panel Data in Emerging Economies', Economics of Transition, 9: 619-633.

Kugler, M. (2001). 'The Diffusion of Externalities from Foreign Direct Investment: The Sectoral Pattern of Technology Spillover', Mimeo: University of Southampton.

Kumar, N. (2005). 'Liberalisation, Foreign Direct Investment Flows and Development: Indian Experience in the 1990s', Economic and Political Weekly, Vol. 40, No. 14 (Apr. 2-8, 2005), pp. 1459-1469

Lall, S. (2004). 'Introduction and Overview', (In Lall, S. and Uratu, S. eds. Competitiveness, FDI and Technological Activity in East Asia. Cheltenham : E. Elgar Publishers).

Lavopa, A. and A. Szirmai (2012). "Manufacturing growth, manufacturing exports and economic development, 1960-2010", paper presented at the 14th International Jospeh A Schumpeter Society Conference, Brisbane, Australia, 2nd-5th July.

Le Bas, C. and Sierra, C. (2002). 'Location versus Home Country Advantages in R\&D Activities: Some Further Results on Multinationals' Locational Strategies', Research Policy, 31 (3): 589-609.

Lederman, D. and Saenz, L. (2005). 'Innovation and Development Around the World, 19602000', World Bank Policy Research Working Paper no. 377

Ki, J. and K. Lee, 'Toward a theory of catch up cycle and industrial leadership. The Case of the World Steel Industry', May, Seoul National University, Department of Economics, 2011 (mimeo).

Li, S. and Xia, J. (2008). 'The Roles and Performance of State Firms and Non-State Firms in China's Economic Transition', World Development, 36 (1): 39-54.

Li, X., Liu, X. and Parker, D. (2001). 'Foreign Direct Investment and Productivity Spillovers in the Chinese Manufacturing Sector', Economic Systems, 25: 305-321.

Li, Y., Wang, H. and Zheng, Y. (2008). 'Enterprise Evolution: Important Path of Industrial TFP Growth in China', Economic Research Journal, 6: 12-24.

Lin, C., Lin, P. and Song, F. (2010). 'Property Rights Protection and Corporate R\&D: Evidence from China', Journal of Development Economics, 93 (1): 49-62. 
Liu, Z. (2008). 'Foreign Direct Investment and Technology Spillovers: Theory and Evidence', Journal of Development Economics, 85: 176-193.

Lloyd, P.J. (1996). 'The Role of Foreign Investment in the Success of Asian Industrialization', Journal of Asian Economics, 7 (3): 407-433.

Lundvall, B.-A. (1992). National Systems of Innovation: Towards a Theory of Innovation and Interactive Learning. London: Pinter.

Marsh, P. (2013). The New Industrial Revolution. Yale: Yale University Press.

Massarani, L. (2012). 'Innovation is 'imperative,' says Brazil science minister', Nature, 25 January (doi:10.1038/nature.2012.9903).

Muendler, M-A. (2004). 'Trade, Technology and Productivity: A Study of Brazilian Manufacturers, 1986-1998', CESIfo Working Paper no. 1148.

Narula, R. and Lall, S. (eds.) (2006). Understanding FDI-assisted economic development. Oxford : Routledge.

Nassif, D. (2007). 'National Innovation Systems and Macroeconomic Policies: Brazil and India in Comparative Perspective', UNCTAD Discussion Paper 184. Geneva.

Naudé, W.A., A. Santos-Paulino, and M. McGillivray (2009). Vulnerability in Developing Countries. Tokyo: UNU Press.

Naudé, W.A. and Szirmai, A. (2012). The Importance of Manufacturing in Economic Development: Past, Present and Future Perspectives. Working Paper, UNU-MERIT. United Nations University.

Nelson, R.R. (1993). National Systems of Innovation: A Comparative Study. New York: Oxford University Press.

Nixson, F. (2012). The Dynamics of Global Value Chain Development: A BRICS Perspective, Paper prepared for the UNIDO project: The Untold Story: Structural Change for Poverty Reduction: The Case of the BRICS, September 2012.

Nordàs, H.K. (2008). 'Vertical Specialization and its Determinants', Journal of Development Studies, 44 (7): 1037-1053.

O'Brien, P.K. (2001). 'Industrialization; Typologies and History of', International Encyclopedia of the Social and Behavioural Sciences, pp. $7360-7367$. 
O’Neill, J. (2001). 'Building Better Global Economic BRICs', in Global Economics Paper No: 66, GS Global Economics Website

Puga, D. and Trefler, D. (2010). 'Wake Up and Smell the Ginseng: International Trade and the Rise of Incremental Innovation in Low-Wage Countries', Journal of Development Economics, 29 (4): 304-313.

Robinson, J. A. (2009). 'Industrial Policy and Development: A Political Economy Perspective'. Paper prepared for the 2009 World Bank ABCDE Conference, Seoul, Korea, 22-24 June.

Rodriguez-Clare, A. (2010). 'Off-shoring in a Ricardian World', American Economic Journal: Macroeconomics, 2(2): 227-258.

Rodrik, D. (2006). 'What's So Special About China's Exports?', China and World Economy, 14: 119.

Romer, P.M. (1994). 'The Origins of Endogenous Growth', Journal of Economic Perspectives, 8 (1): 3-22.

Sachs, J.D. (1996). 'Notes on the Life Cycle of State-Led Industrialization', Japan and the World Economy, 8: 153-174.

Saggi, K. (2002). 'Trade, Foreign Direct Investment, and International Technology Transfer: A Survey', World Bank Research Observer, 17 (2): 191-235.

Saliola, F. and Zanfei, A. (2009). 'Multinational Firms, Global Value Chains and the Organization of Knowledge Transfers', Research Policy, 38 (): 369-381.

Saxenian, A. (2006). The New Argonauts: Regional Advantage in a Global Economy. Cambridge MA: Harvard University Press.

Schott, P.K. (2008). 'The Relative Sophistication of Chinese Exports', Economic Policy, 23 (53): 5 49.

Subramanian, A. (2011). Eclipse: Living in the Shadow of China's Economic Dominance. Washington DC: Peterson Institute for International Economics.

Subramanian, A. (2012). 'Have the BRICS Outlived Their Usefulness?', Peterson Perspectives : Interviews on Current Topics, 29 March 2012, available at http://www.iie.com/publications/interviews/pp20120328subramanian-brics.pdf 
Syrquin, M. (1988). 'Patterns of Structural Change'. In H. B. Chenery and T. N. Srinivasan (eds), Handbook of Development Economics, vol. 1. Amsterdam: Elsevier Science Publishers, 203-73.

Szirmai, A. (2005). Dynamics of socio-economic development. Cambridge: Cambridge University Press.

Szirmai, A. (2012a). 'Industrialization as an Engine of Growth in Developing Countries, 19502005', Structural Change and Economic Dynamics, , 23 (4), December 2012, pp. 406-20, http://www.sciencedirect.com/science/article/pii/S0954349X1100018X

Szirmai, A (2012b). Proximate, Intermediate and Ultimate Causality: Theories and Experiences of Growth and Development, Working Papers on Institutions and Economic Growth: IPD WP01), UNU-MERIT Working Paper Series, 2012-32, May 2012 (76 pp).

Szirmai, A. (2012c). 'Explaining Success and Failure in Economic Development' in D.S. Prasada Rao and B. van Ark, (eds.), World Economic Performance. Past, Present and Future, Edward Elgar, chapter 9.

Szirmai, A., Naudé, W.A. and Alcorta, L. eds. (2013). Pathways to Industrialization in the $21^{\text {st }}$ Century. Oxford: Oxford University Press.

Tang, M. and Hussler, C. (2011). 'Betting on Indigenous Innovation or Relying on FDI: The Chinese Strategy for Catching Up', Technology in Society, 33: 23-35.

Thomas, L., and Leape, J. (2005). 'Foreign Direct investment in South Africa: The initial impact of the Trade, Development, and Cooperation Agreement between South Africa and the European Union', CREFSA, London School of Economics, October.

Timmer, M. and Szirmai, A. (2000). 'Productivity Growth in Asian Manufacturing: the Structural Bonus Hypothesis Examined', Structural Change and Economic Dynamics, 11: 371-392.

Tregenna, F. (2011). 'Manufacturing Productivity, Deindustrialization, and Reindustrialization', UNU-WIDER Working Paper no. 2011-57, Helsinki.

Tuan, C., Ng, L., F., Y., and Zhao, B. (2009) 'China's post-economic reform growth: The role of FDI and productivity progress', Journal of Asian Economics 20, 280-293.

Thurik, R. (2010). 'From the Managed to the Entrepreneurial Economy: Considerations for Developing and Emerging Economies', (In Naudé, W.A. ed. Entrepreneurship and Economic Development. London: Palgrave McMillan. Pp. 147-165). 
UNCTAD (2005). World Investment Report 2005: TNCs and the Internationalization of R\&D. Geneva: United Nations Conference on Trade and Development.

UNCTAD (2011). World Investment Report 2011: Non Equity Modes of International Production and Development. Geneva: United Nations Conference on Trade and Development.

Van Ark, B. and M. Timmer (2003). 'Asia's Productivity Performance and Potential: The Contribution of Sectors and Structural Change'. In: The Conference Board.

Van Dijk, M. (2002). 'South African manufacturing performance in international perspective, 1970-1999', GGDC Research Memorandum 200258, Groningen Growth and Development Centre, University of Groningen.

Veloso, F. and Soto, J.M. (2001). 'Incentives, Infrastructure and Institutions: Perspectives on Industrialization and Technical Change in Late-Developing Nations', Technological Forecasting and Social Change, 66: 87-109.

Verspagen, B. (2004). 'Innovation and Economic Growth', in: J. Fagerberg, D.C. Mowery and R.R. Nelson (eds), The Oxford Handbook of Innovation, Oxford: Oxford University Press, 487-513.

Von Tunzelmann, G.N. (1995). Technology and Industrial Progress: The Foundations of Economic Growth. Aldershot: E. Elgar Publishers.

Von Tunzelmann, G.N. (1997). 'Innovation and Industrialization: A Long-Term Comparison', Technological Forecasting and Social Change, 56: 1-23.

Wang, J. and Blomström, M. (1992). 'Foreign Investment and Technology Transfer: A Simple Model', European Economic Review, 36 (1): 137

Wang, L. and A. Szirmai (2008). 'Productivity growth and structural change in Chinese manufacturing, 1980-2002', Industrial and Corporate Change, Oxford University Press, vol. 17(4), pages 841-874, August.

Wang L., H. Meijer and A. Szirmai (2013) Technological Spillovers and Industrial Growth in Chinese Regions, mimeo, under review

Wilson, D. And Purushotothaman, R. (2003). 'Dreaming with the BRICs: The Path to 2050', Goldman Sachs Research Paper no. 99.

Wright, G. (1990). 'The Origins of American Industrial Success, 1879-1940', American Economic Review, 80 (3): 651-668. 
Xiwei, Z. and Xiangdong, Y. (2007). 'Science and Technology Policy Reform and its Impact on China's National Innovation System', Technology in Society, 29: 317-325.

Yi, K.M. (2003). 'Can Vertical Specialization Explain the Growth of World Trade?', Journal of Political Economy, 11 (1): 52 - 102.

Yueh, L. (2009). 'Patent Laws and Innovation in China', International Review of Law and Economics, 29 (4): 304-313.

Zheng, L. and Xue, L. (2010). 'The Evolution of China's IPR System and its Impact on the Patenting Behaviours and Strategies of Multinationals in China', International Journal of Technology Management, 51 (2-4): 469-496.

Zhou, P. and Leydesdorff, L. (2006). 'The Emergence of China as a Leading Nation in Science', Research Policy, 35 (1): 83-104. 


\section{Appendix: Description of Data}

In this appendix we detail the main data sources and methods used to construct the tables on sectoral distribution of FDI in BRICS countries (Tables 11 and 12).

\section{BRAZIL}

1981-1995:

Sectoral distribution of FDI based on "Distribuição por ramo de atividade da empresa receptora (1980-Jun/1995)"

\section{(http://www.bcb.gov.br/?INVEDIR)}

The original data refers to yearly stocks of FDI. Flows have been calculated as yearly differences in the stocks and thus include both (inward and outward) FDI. To build the sectoral distribution, negative variations (sectors in which the stock decreased between two years) were imputed as zero.

Sectoral distribution of FDI based on "Investimento estrangeiro direto Tabelas - Censo 1995 e ingressos 1996 a 2000"

1996-2000: $\quad$ http://www.bcb.gov.br/rex/IED/Port/ingressos/htms/index1.asp?idpai=l NVEDIR

The original data refers to yearly flows.

Sectoral distribution of FDI based on "Investimento estrangeiro direto Tabelas - Censos 1995/2000 e ingressos 2001 a 2006"

2001-2006

http://www.bcb.gov.br/rex/IED/Port/ingressos/htms/index2.asp?idpai=I NVEDIR

The original data refers to yearly flows.

"Sectoral distribution of FDI based on "'"Investimento estrangeiro direto Tabelas - Ingressos a partir de 2007"

2007-2009 http://www.bcb.gov.br/rex/IED/Port/ingressos/htms/index3.asp?idpai=I NVEDIR

The original data refers to yearly flows

\section{RUSSIA}


Sectoral distribution of FDI based on Iwasaki and Suganuma (2005).

This paper presents information of FDI by sector based on Goskomstat RF (2001, 2003a, 2004). Unfortunately the disaggregation is lower than the

1995-2003: one used here and thus some sectors include part of FDI which belongs to other sectors.

For the years 1998-2000 there is also information available at UNCTAD. Since it is very similar to the one presented in Iwaski and Suganuma (2005) but for a shorter period, we decided to use the latter source.

Sectoral distribution of FDI based on Federal State Statistics Service: "Russia in Figures. Table 23.11", various issues.

2005-2010:

http://www.gks.ru/wps/wcm/connect/rosstat/rosstatsite/main/publishin g/catalog/statisticCollections/doc 1135075100641 
$\underline{\text { INDIA }}$

Sectoral distribution of FDI based on Kumar (2005).

1980 and 1990:

The original data refers to FDI stocks. Unfortunately it was not possible to calculate the implicit FDI inflows. Thus we assumed that the distributions of the FDI stock in 1990 is representative of the distribution of FDI inflows during 1986-1990

Sectoral distribution of FDI based on SIA Newsletter, January edition for the years: 1999 to 2005 (http://dipp.gov.in/English/Archive/Archive.aspx)

1991-2004:

The original data refers to cumulative inflows of FDI starting on August 1991. Flows have been calculated as yearly differences in the cumulative inflows.

Sectoral distribution of FDI based on SIA Newsletter, January edition for

2005-2010: the years: 2006 to 2011 (http://dipp.gov.in/English/Archive/Archive.aspx)

The original data refers to yearly inflows.

\section{CHINA}

1984, 1988 and Sectoral distribution of FDI based on Broadman and Sun (1997).

1993:

1995-2010: $\quad$ Statistical Yearbook (CSY), various issues.

http://www.stats.gov.cn/english/statisticaldata/yearlydata/

Note: Given the lack of information on FDI by industrial sectors within manufacturing, a proxy estimation has been used. This proxy is based on yearly figures of Fix Assets in Foreign firms by industrial sector published in the CSY. Sectoral FDI has been approximated as the yearly change in fix assets of foreign founded enterprises in each industry.

\section{SOUTH AFRICA}

1994-2004

Sectoral distribution of FDI based on UNCTAD "WID Country Profile - South 
Africa", which presents information from the African Reserve Bank. This information, however, has no disaggregation within manufacturing, Transport and Business services.

The distribution within manufacturing, transport and business services is based on Thomas and Leape (2005), which make use of the BusinessMap Foundation Database.

Sectoral distribution of FDI based on South African Reserve Bank, Quarterly Bulletin, December Edition for the years 2004 to 2011

2004-2010

http://www.resbank.co.za/Publications/QuarterlyBulletins/Pages/QuarterlyBulletin.aspx 